\title{
The Role of Plant Growth Promoting Rhizosphere Microbiome as Alternative Biofertilizer in Boosting Solanum melongena $\mathrm{L}$. Adaptation to Salinity Stress
}

\author{
Souhair Mokabel ${ }^{1}$, Zakia Olama ${ }^{1}$, Safaa Ali ${ }^{2}$ (D) and Rehab El-Dakak ${ }^{1, *(D)}$ \\ 1 Department of Botany and Microbiology, Faculty of Science, Alexandria University, Alexandria 21511, Egypt; \\ souhair.mokabel@alexu.edu.eg (S.M.); zakia.olama@alexu.edu.eg (Z.O.) \\ 2 Nucleic Acid Research Department, Genetic Engineering and Biotechnology Research Institute, City of \\ Scientific Research and Technology Applications (SRTA-City), Alexandria 21934, Egypt; sali@srtacity.sci.eg \\ * Correspondence: rehab.eldakak@alexu.edu.eg
}

check for updates

Citation: Mokabel, S.; Olama, Z.; Ali, S.; El-Dakak, R. The Role of Plant Growth Promoting Rhizosphere Microbiome as Alternative Biofertilizer in Boosting Solanum melongena L. Adaptation to Salinity Stress. Plants 2022, 11, 659. https:// doi.org/10.3390/plants11050659

Academic Editor: Arafat Abdel Hamed Abdel Latef

Received: 29 January 2022 Accepted: 21 February 2022 Published: 28 February 2022

Publisher's Note: MDPI stays neutral with regard to jurisdictional claims in published maps and institutional affiliations.

Copyright: (c) 2022 by the authors. Licensee MDPI, Basel, Switzerland. This article is an open access article distributed under the terms and conditions of the Creative Commons Attribution (CC BY) license (https:// creativecommons.org/licenses/by/ $4.0 /)$.

\begin{abstract}
Recent ecological perturbations are presumed to be minimized by the application of biofertilizers as a safe alternative to chemical fertilizers. The current study aims to use bioinoculum (I) as an alternative biofertilizer and to alleviate salinity stress in the cultivar Solanum melongena L. Baldi. The salinity drench was $200 \mathrm{mM} \mathrm{NaCl}$ (S), which was used with different treatments (0; I; S; S + I) in pots prefilled with clay and sand (1:2). Results showed that salinity stress inhibited both plant fresh and dry weights, water content, and photosynthetic pigments. The content of root spermine (Spm), spermidine (Spd), and puterscine (Put) decreased. However, addition of the bioinoculum to salt-treated plants increased pigment content $(80.35,39.25$, and $82.44 \%$ for chl a, chl b, and carotenoids, respectively). Similarly, $\mathrm{K}+, \mathrm{K}+/ \mathrm{Na}+, \mathrm{Ca} 2+, \mathrm{P}$, and $\mathrm{N}$ contents were significantly enhanced. Increases were recorded for Spm + Spd and Put in root and shoot (8.4-F, 1.6-F and 2.04-F, 2.13-F, respectively). RAPD PCR showed gene expression upregulation of photosystem II D2 protein, glutathione reductase, glutathione-S-transferase, protease I, and protease II. The current work recommends application of the selected bioinoculum as a green biofertilizer and biopesticide. Additionally, the studied eggplant cultivar can be regarded as a source of salt tolerance genes in agricultural fields.
\end{abstract}

Keywords: biofertilizer; biopesticide; eggplant; gene expression; physiological traits; polyamines; salinity; stress; Solanum melongena

\section{Introduction}

Chemical fertilizers have been widely used to achieve maximum crop productivity in conventional agricultural systems. Nevertheless, when chemical fertilizers exceed the threshold level, they accelerate soil acidification, pollute groundwater, and harm the environment overall [1]. It is recommended to apply biofertilizers as eco-friendly alternatives as they play a pivotal role in phosphate solubilization, nitrogen fixation, production of ammonia, enzymes, siderophores, and secretion of variable phytohormones. Furthermore, they exhibit biocontrol activity against a wide variety of phytopathogenic agents [2]. Bhattacharyya and Jha [3] observed that inoculation of bacteria and fungi into the soil or seedling roots may colonize either the rhizosphere or the inner sections of the plants, thus enhancing plant growth and development.

The application of microbes can be used to enhance systemic tolerance in plants against biotic as well as environmental stress. Bacillus subtilis inhibits pathogens causing diseases either directly or indirectly through a biocontrol mechanism [4]. Some Pseudomonas species stimulate plant growth through the production of water-soluble vitamins like niacin [5]. Besides, specific mycorrhizal fungi like Trichoderma harzianum that act as plant symbionts can be widely used for their ability to induce plant tolerance to biotic and abiotic stresses such as salinity and drought [6]. Moreover, inoculation of Aspergillus terreus enhances $\mathrm{NaCl}$ 
tolerance in Pennisetum glaucum by mitigating the physicochemical attributes of the host plant [7]. Interestingly, the plant growth promoting ability of Pinicillium critinum initiates habitat revegetation and conservation. Also, its production of $\mathrm{GA}_{5}$ from gibberellins opens new insights in research and investigation [8].

Eggplant (Solanum melongena) is the fifth most economically important crop within the Solanaceae family and is considered by the Food and Agriculture Organization of the United Nations (FAO) as one of the 35 foods with the most considerable relevance for world food security [9]. In this respect, Egypt is ranked third out of the top five producing countries of eggplant [10]. Because eggplant has a relatively long growth period, it is more exposed than other vegetable crops to a broad range of plant diseases, pests, nematodes, and weeds [11].

Excess salts in soil pose a serious threat to agricultural production and environmental health [12]. Soil salinity is a widespread problem that extends over one billion hectares spread across many countries. If left abandoned, this condition could develop into a socioeconomic and human health problem in the long run [13].

Eggplant is a sensitive species to salinity and is not well adapted to saline soils [14]. Thus, one of the objectives of this study was to select the best combination of plant growth promoting rhizobcteria (PGPR) and rhizo fungi (RF) for eggplant growth in saline soil and investigate the alleviative role of combining the selected bioinoculum on salinity stress in Solanum melongena L. Baldi cultivar. Another objective was to elucidate the physiological and molecular systemic resistance exhibited by eggplant to withstand salt stress. Finally, a question was posed to establish whether the selected bioinoculum applied is recommended (or not) in agricultural fields as a biofertilizer/biopesticide alternative to chemical fertilizers.

\section{Results}

\subsection{Molecular Identification and Phylogeny of Bacterial Isolates in the Selected Bioinoculum}

Identification of the most promising isolates, B1, B4, and B7, was carried out using $16 \mathrm{~S}$ rDNA (Figure 1). Agarose gel (1\%) was used to examine the PCR results, where the $1500 \mathrm{bp}$ amplified fragment's sequence was easily determined. The sequences of various types of strains from the gene bank were a popular tool for identifying and classifying prokaryotes. Thus, when the gene sequences (16 s) of the selected bacterial isolates were compared to those of the gene bank, the isolate code B1 (B1SRZS) was found to be 99.71 percent identical to Bacillus subtilis with accession no. MT214144.1 (Figure 2a), the isolate code B4 (B4SRZS) was found to be 99 percent identical to Bacillus subtilis with accession no. MH359177.1 (Figure 2b), and the isolate code B7SRZS was found to be 99 percent identical to Pseudomonas sp. with accession number KR054995.1 (Figure 2c). Supplementary Tables S3-S5 show the percentages of similarity and accession numbers obtained after comparing the sequences of the tested strains to the sequences submitted to Gene Bank.

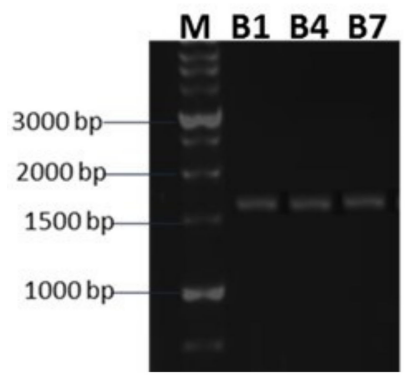

Figure 1. Agarose gel electrophoresis of the amplified PCR fragment for $16 \mathrm{r}$ DNA gene. M: $1 \mathrm{~kb}$ DNA marker, isolates with code no. (B1, B4 and B7) (MW 1550 bp). 


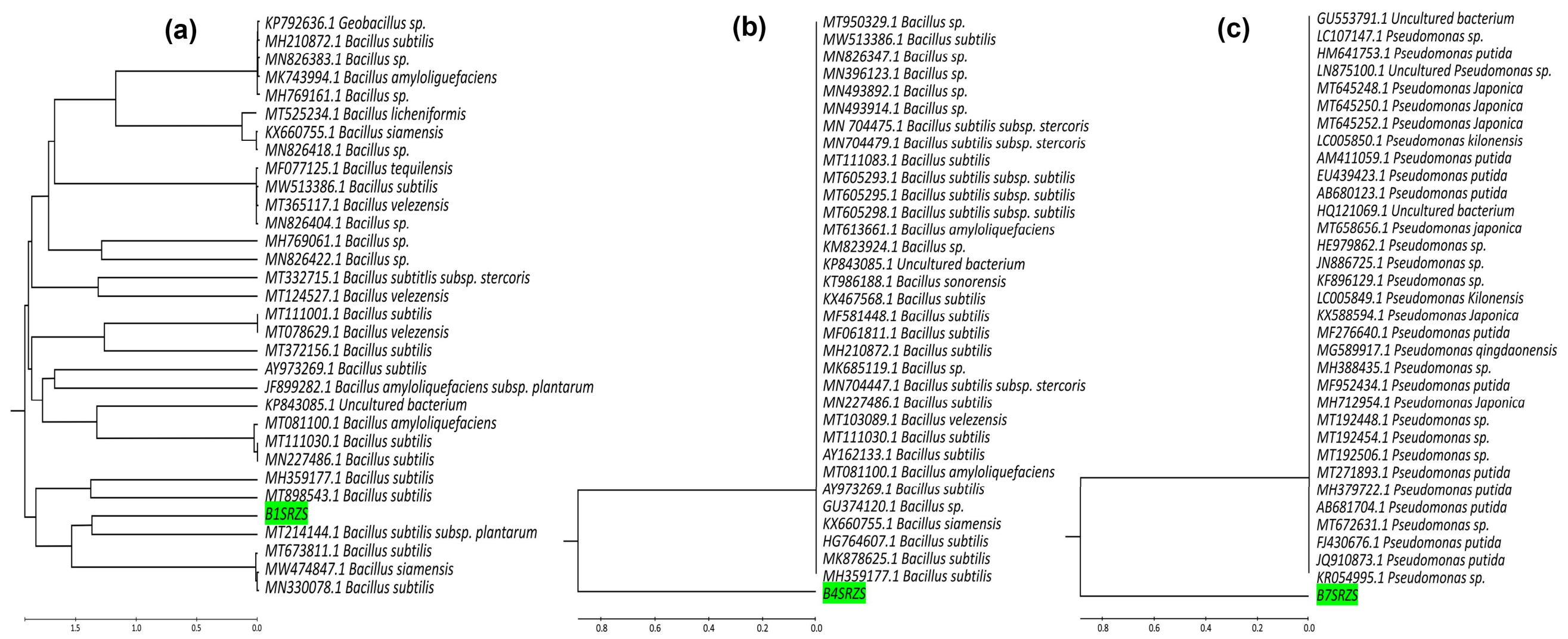

Figure 2. Phylogenetic tree of isolate coded B1SRZS, B4SRZS, and B7SRZS ((a-c), respectively) achieved, displaying the location amid the selected bacteria based on 16Sr RNA sequence assessments. 


\subsection{Solanum melongena L. Salt Tolerance Indices Percentage as Affected by Salt Stress and/or Inoculum Treatments}

Solanum melongena L. seeds were germinated and grown in sandy clay soil for 66 days and treated with the selected PGPR and RF alone and in combination with $200 \mathrm{mM} \mathrm{NaCl}$. At the end of the experimental period, the role of selected inoculum of PGPR and RF was assessed in morphometric traits including plant height (PH), root length (RL), shoot length (SL), R/S ratio, individual and total root and shoot; fresh and dry weights (RFW; RDW; SFW; SDW; TFW; TDW), and leaf area (LA), in addition to individual and total root and shoot water content (RWC; SWC; TWC). Salinity stress significantly decreased leaf area, root fresh and dry weights, in addition to root water content by $(59.14,95.87,96.30$, and $95.66 \%$, respectively) compared to control (Supplementary Data-Tables S1 and S2). Inoculating the soil of salt-stressed eggplants showed a significant increase in leaf area, total fresh, dry weight, and water content (by 1.95-F, 3.53-F, 3.97-F, and 3.42-F, respectively) compared to salt-stressed plants (Supplementary Data-Tables S1 and S2). Salt tolerance indices percentage (STI\%) revealed that the selected inoculum significantly increased salinity tolerance of eggplant morphometric traits except for PH, RL, SL, R/S ratio, and LA (Table 1). The significant increase in STI\% was recorded for RFW, SFW, TFW, RDW, SDW, TDW, RWC, SWC, and TWC (17.67-F, 2.98-F, 4.90-F, 19.88-F, 3.79-F, 7.37-F, 16.82-F, 2.82-F, and 4.4-F, respectively).

Table 1. Solanum melongena L. salt tolerance indices percentage as affected by $200 \mathrm{mM} \mathrm{NaCl}(\mathrm{S})$ and/or inoculum (I) treatments.

\begin{tabular}{ccccc}
\hline STI\% of Parameters & S & S + I & T & $p$ \\
\hline PH & $76.89 \pm 11.62$ & $82.41 \pm 11.65$ & 0.581 & 0.592 \\
RL & $118.61 \pm 28.20$ & $112.53 \pm 24.45$ & 0.282 & 0.792 \\
SL & $60.35 \pm 12.71$ & $70.93 \pm 17.23$ & 0.856 & 0.440 \\
R/S & $204.65 \pm 69.85$ & $167.30 \pm 59.26$ & 0.706 & 0.519 \\
RFW & $4.12^{*} \pm 0.55$ & $72.79 \pm 39.92$ & $2.979 *$ & $0.041^{*}$ \\
SFW & $16.97 * \pm 5.20$ & $50.56 \pm 6.48$ & $7.002^{*}$ & $0.002^{*}$ \\
TFW & $11.03^{*} \pm 1.54$ & $54.07 \pm 11.72$ & $6.310^{*}$ & $0.022^{*}$ \\
RDW & $3.68 \pm 0.33$ & $73.14 \pm 36.09$ & $3.333^{*}$ & $0.029^{*}$ \\
SDW & $17.35^{*} \pm 2.93$ & $65.79 \pm 15.08$ & $5.459 *$ & $0.005^{*}$ \\
TDW & $9.12^{*} \pm 0.23$ & $67.21 \pm 20.81$ & $4.834^{*}$ & $0.040^{*}$ \\
RWC & $4.35^{*} \pm 0.71$ & $73.15 \pm 42.58$ & $2.798^{*}$ & $0.049^{*}$ \\
SWC & $16.90 * \pm 5.69$ & $47.71 \pm 5.13$ & $6.964 *$ & $0.002^{*}$ \\
TWC & $11.64^{*} \pm 1.98$ & $51.18 \pm 9.91$ & $6.774^{*}$ & $0.002^{*}$ \\
LA & $41.24 \pm 5.95$ & $92.68 \pm 35.89$ & 2.449 & 0.128 \\
\hline
\end{tabular}

Note: STI \% = salt tolerance index percentage; PH = plant height; RL = root length; SL = shoot length $\mathrm{R} / \mathrm{S}=$ root/shoot ratio; RFW = root fresh weight; $\mathrm{SFW}=$ shoot fresh weight; TFW = total fresh weight; RDW = root dry weight; SDW = shoot dry weight; TDW = total dry weight; RWC = root water content; SWC = shoot water content; TWC = total water content; and LA = leaf area. Parameters measured 66 days after sowing. Values are means $\pm \mathrm{SD}$ based on triplicate independent determinations, * means statistically significant difference at $p \leq 0.05$, t: Student $t$-test.

\subsection{Solanum melongena L. Leaves Photosynthetic Pigments and Chlorophyll Fluorescence as Affected by Salt Stress and/or Inoculum Treatments}

The effect of the selected microbiome on photosynthetic pigments revealed that under salinity stress all pigments were significantly decreased compared to control (Table 2). Nevertheless, inoculating $S$, melongena L. plants after exposure to salinity stress resulted in a significant increase in chl a, chl b, chl a $+b, c h l a / b$, and carotenoid content by (80.35, $39.25,69.20,29.37$, and $82.44 \%$, respectively) compared to salt stressed plants. 
Table 2. Solanum melongena L. leaves photosynthetic pigments as affected by $200 \mathrm{mM} \mathrm{NaCl}(\mathrm{S})$ and/or inoculum (I) treatments.

\begin{tabular}{|c|c|c|c|c|}
\hline \multirow{2}{*}{ Parameters } & \multicolumn{4}{|c|}{ Treatments } \\
\hline & $\mathrm{C}$ & I & $S$ & $S+I$ \\
\hline $\begin{array}{c}\text { Chl a } \\
(\mu \mathrm{gg}-1 \mathrm{FW})\end{array}$ & $10.11^{a} \pm 0.78$ & $7.38^{b} \pm 0.61$ & $5.75^{b} \pm 0.77$ & $10.37^{a} \pm 2.39$ \\
\hline $\begin{array}{c}\text { Chl b } \\
(\mu \mathrm{gg}-1 \mathrm{FW})\end{array}$ & $3.30^{\mathrm{a}} \pm 0.38$ & $1.99^{c} \pm 0.11$ & $2.14^{\mathrm{bc}} \pm 0.09$ & $2.98^{a b} \pm 0.82$ \\
\hline $\begin{array}{c}\text { Chl a + b } \\
(\mu \mathrm{g} g-1 \mathrm{FW})\end{array}$ & $13.41^{\mathrm{a}} \pm 0.74$ & $9.36^{b} \pm 0.71$ & $7.89^{b} \pm 0.85$ & $13.35^{\mathrm{a}} \pm 3.20$ \\
\hline $\mathrm{Chl} a / \mathrm{b}$ & $3.06^{b} \pm 0.23$ & $3.71^{a} \pm 0.02$ & $2.69^{c} \pm 0.08$ & $3.48^{a} \pm 0.05$ \\
\hline $\begin{array}{c}\text { Carot. } \\
(\mu \mathrm{g} g-1 \mathrm{FW})\end{array}$ & $2.36^{\mathrm{a}} \pm 0.24$ & $1.78^{b} \pm 0.11$ & $1.31^{\mathrm{b}} \pm 0.12$ & $2.39^{a} \pm 0.49$ \\
\hline $\mathrm{F}_{\mathrm{v}} / \mathrm{F}_{\mathrm{m}}$ & $0.79^{a} \pm 0.01$ & $0.79^{a} \pm 0.03$ & $0.75^{a} \pm 0.02$ & $0.76^{a} \pm 0.02$ \\
\hline $\mathrm{F}_{\mathrm{v}} / \mathrm{F}_{0}$ & $3.84^{a} \pm 0.27$ & $3.76^{a} \pm 0.60$ & $2.98^{a} \pm 0.36$ & $3.38^{a} \pm 0.31$ \\
\hline
\end{tabular}

Note: $\mathrm{C}=$ control; $\mathrm{Chl} \mathrm{a}=$ chlorophyll $\mathrm{a} ; \mathrm{Chl} \mathrm{b}=$ chlorophyll $\mathrm{b} ; \mathrm{Chl} \mathrm{a}+\mathrm{b}=$ chlorophyll $\mathrm{a}$ and $\mathrm{b} ; \mathrm{Chl} \mathrm{a/b}=$ chlorophyll $\mathrm{a} / \mathrm{b}$; Carot. = carotenoids; $\mathrm{Fv} / \mathrm{Fm}=$ variable to maximum fluorescence; and $\mathrm{Fv} / \mathrm{F} 0=$ variable to ground fluorescence. Parameters measured 66 days after sowing. Values are means $\pm \mathrm{SD}$ based on triplicate independent determinations, and different letters means significant difference as evaluated by Duncan's multiple comparison test $(p<0.05)$.

Examination of the maximum quantum efficiency and photochemical efficiency of PSII using chlorophyll fluorescence expressed by $\mathrm{F}_{\mathrm{v}} / \mathrm{F}_{\mathrm{m}}$ and $\mathrm{F}_{\mathrm{v}} / \mathrm{F}_{0}$ unexpectedly showed insignificant change among all treatments tested.

\subsection{Element Homeostasis in Solanum melongena L. as Affected by Salt Stress and/or Inoculum Treatments}

To detect the elemental homeostasis in S. melongena plants, the element contents $\left(\mathrm{K}^{+}\right.$, $\mathrm{Na}^{+}, \mathrm{K}^{+} / \mathrm{Na}^{+}, \mathrm{Mg}^{2+}, \mathrm{Ca}^{2+}, \mathrm{P}$, and N) of shoots and roots were determined (Figure 3). Under salinity stress, a significant decrease was observed for all ions except for $\mathrm{Na}^{+}$compared to control. In contrast, no significant effect of $\mathrm{Mg}^{2+}$ was recorded for S. melongena root or shoot. In the case of the double interaction $\mathrm{S}+\mathrm{I}$, there was a significant increase for $\mathrm{K}^{+}$, $\mathrm{K}^{+} / \mathrm{Na}^{+}, \mathrm{Ca}^{2+}, \mathrm{P}$, and $\mathrm{N}$ ions $(2,2.8,5.6,1.2,1.3-\mathrm{F}$ in root and 1.4, 2.6, 1.3, 1.2, 1.16-F in shoot, respectively). Whereas, $\mathrm{Na}^{+}$showed an opposite trend to the other measured ions compared with salt-stressed plants.

Interestingly, ions such as $\mathrm{K}^{+}, \mathrm{K}^{+} / \mathrm{Na}^{+}, \mathrm{Ca}^{2+}, \mathrm{P}$, and $\mathrm{N}$ were found to be transported actively from roots to shoots (Translocation factor $(\mathrm{TF})=3.4,4.7,1.9,2.4$, and 3.4, respectively) at $\mathrm{S}+\mathrm{I}$ treatment, whereas $\mathrm{Na}^{+}$attained relatively lower values ( $\mathrm{TF}=0.71$ and 0.9 , respectively). The relative high translocation factor for measured ions in inoculated S. melongena after salinity stress suggests the presence of a transport system somehow for these ions from root to shoot as a defense mechanism towards salt stress.

\subsection{Hormonal Status in Salt-Stressed Solanum melongena L. as Affected by Salt Stress and/or Inoculum Treatments}

Quantification of free polyamines in S. melongena L. plants showed that salinity-stress significantly decreased Spmand Spd. levels in roots (by 100 and 68, respectively), while it increased Spm and Spd levels in shoots by $26 \%$ and $113 \%$, respectively with respect to control (Table 3). Inoculation with selected PGPR and RF caused a marked increase in levels of Spm + Spd and Put in the root as well as the shoot (8.4-F, 1.6-F and 2.04-F, 2.13-F, respectively) compared to salt-stressed plants. It is also notable that root Put $\left(2.37 \mathrm{mg} \cdot \mathrm{g}^{-1} \mathrm{FW}\right)$ was greater than Spm $+\mathrm{Spd}\left(0.84 \mathrm{mg} \cdot \mathrm{g}^{-1} \mathrm{FW}\right)$ in bioinoculated salt stressed eggplants compared to $S$, whereas shoot Put $\left(0.17 \mathrm{mg} \cdot \mathrm{g}^{-1} \mathrm{FW}\right)$ attained lower values than $\mathrm{Spm}+\mathrm{Spd}\left(1.14 \mathrm{mg} \cdot \mathrm{g}^{-1} \mathrm{FW}\right)$. 


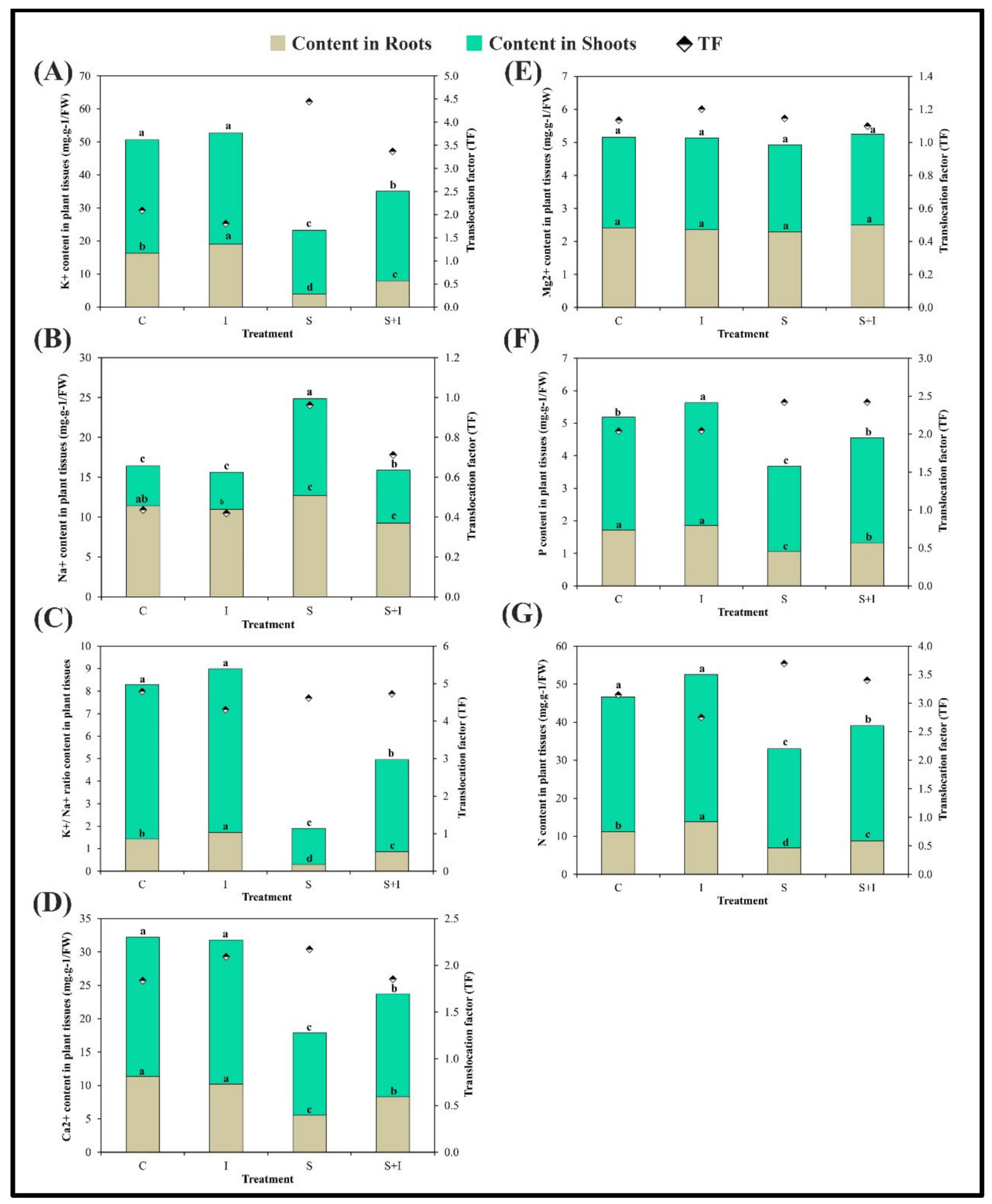

Figure 3. Effect of $0(\mathrm{C})$, selected bioinoculum (I), $200 \mathrm{mM} \mathrm{NaCl}(\mathrm{S})$, and their interactions on elements content: $(A)=$ potassium $(K+),(B)=$ sodium $(\mathrm{Na}+),(\mathbf{C})=\mathrm{K}+/ \mathrm{Na}+$ ratio, $(\mathbf{D})=$ calcium $(\mathrm{Ca} 2+) .(\mathrm{E})=$ magnesium $(\mathrm{Mg} 2+),(\mathrm{F})=$ phosphorous $(\mathrm{P})$, and $(\mathrm{G})=$ nitrogen $(\mathrm{N})$ and translocation factor (TF) (mineral content in shoots/mineral content in roots) in the roots and shoots of S. melongena L. plants 66 days after sowing. Values are means \pm SD based on triplicate independent determinations, and different letters means a significant difference as evaluated by Duncan's multiple comparison test $(p<0.05)$. 
Table 3. Hormonal Status in Solanum melongena L. roots and shoots as affected by Salt Stress and/or inoculum treatments.

\begin{tabular}{|c|c|c|c|c|c|c|c|c|}
\hline \multirow{3}{*}{ Parameters } & \multicolumn{8}{|c|}{ Treatment } \\
\hline & \multicolumn{4}{|c|}{ Roots } & \multicolumn{4}{|c|}{ Shoots } \\
\hline & $\mathrm{C}$ & I & $S$ & $S+I$ & $\mathrm{C}$ & I & $S$ & $S+I$ \\
\hline $\begin{array}{c}\text { Spm } \\
\left(\mathrm{mg} \mathrm{g}^{-1} \mathrm{FW}\right)\end{array}$ & $0.58^{b} \pm 0.01$ & $0.0^{\mathrm{c}} \pm 0.0$ & $0.0^{c} \pm 0.0$ & $0.66^{\mathrm{a}} \pm 0.02$ & $0.31^{\mathrm{d}} \pm 0.02$ & $0.80^{b} \pm 0.04$ & $0.39^{c} \pm 0.02$ & $0.93^{\mathrm{a}} \pm 0.02$ \\
\hline $\begin{array}{c}\text { Spd } \\
\left(\mathrm{mg} \mathrm{g}^{-1} \mathrm{FW}\right)\end{array}$ & $0.31^{\mathrm{a}} \pm 0.02$ & $0.0^{\mathrm{d}} \pm 0.0$ & $0.10^{c} \pm 0.01$ & $0.18^{\mathrm{b}} \pm 0.01$ & $0.08^{c} \pm 0.02$ & $0.10^{c} \pm 0.01$ & $0.17^{b} \pm 0.01$ & $0.21^{\mathrm{a}} \pm 0.02$ \\
\hline $\begin{array}{c}\text { Put } \\
\left(\mathrm{mg} \mathrm{g}^{-1} \mathrm{FW}\right)\end{array}$ & $3.37^{a} \pm 0.07$ & $0.18^{\mathrm{d}} \pm 0.01$ & $1.50^{c} \pm 0.03$ & $2.37^{b} \pm 0.02$ & $0.08^{b} \pm 0.01$ & $0.03^{c} \pm 0.01$ & $0.08^{b} \pm 0.02$ & $0.17^{\mathrm{a}} \pm 0.02$ \\
\hline $\begin{array}{c}\text { Prol } \\
\left(\mu \mathrm{g} \mathrm{g}^{-1} \mathrm{FW}\right)\end{array}$ & $\begin{array}{c}10.35^{c} \pm \\
0.28\end{array}$ & $7.73^{d} \pm 0.67$ & $\begin{array}{c}16.22^{b} \pm \\
0.30\end{array}$ & $\begin{array}{c}19.22^{\mathrm{a}} \pm \\
1.22\end{array}$ & $\begin{array}{c}18.71^{\mathrm{c}} \pm \\
1.43\end{array}$ & $8.87^{d} \pm 0.26$ & $\begin{array}{c}24.37^{b} \\
0.29\end{array}$ & $\begin{array}{c}30.05^{\mathrm{a}} \pm \\
0.54\end{array}$ \\
\hline
\end{tabular}

Note: $\mathrm{C}=$ control; $\mathrm{Spm}=$ spermine; $\mathrm{Spd}=$ spermidine; Put = putersciene; and Prol = proline. Parameters measured 66 days after sowing. Values are means $\pm S D$ based on triplicate independent determinations, and different letters means significant difference as evaluated by Duncan's multiple comparison test $(p<<0.001)$.

To investigate the mechanisms related to osmotic adjustment, it is necessary to incorporate measurement of proline content in roots and shoots of S. melongena under normal and stressed conditions. The results presented in Table 3 showed that there was an increase in proline content under salinity stress by $57 \%$ and $30 \%$ in root and shoot, respectively, compared to control. Application of the selected bioinoculum to salt-stressed eggplants resulted in a significant increase in proline content of roots and shoots by $18.50 \%$ and $23.31 \%$, respectively, compared to salt-stressed pots.

2.6. Selected Inoculum Modulates Some Genes Related to Defense System of Salt-Stressed Solanum melongena L. Roots and Shoots

The measurements of parameters at the molecular levels are essential to understand the defense mechanism of inoculated eggplant after exposure to salinity stress.

The fold of gene expression for five genes related to different physiological aspectsphotosynthesis, glutathione, lipids, and proteins-is represented in Figure 4. These genes are related to variable physiological aspects: photosynthesis, glutathione, lipids, and proteins.

The gene of psbD related to D2 protein participates in the D1/D2 heterodimer of PSII complex where it binds with cofactors to facilitate e-transfer for ATP formation (Figure 4a). The gene expression of shoot psbD was upregulated about 5-fold after inoculation of salt-stressed eggplants.

Glutathione reductase (GR) plays an important role in the ascorbate-glutathione cycle under abiotic stress. The gene expression of GR in the current study was increased by about 4 -fold and 2-fold for root and shoot, respectively at S + I compared to salt stressed pots (Figure $4 b$ ).

Glutathione S-transferase (GST) minimizes reactive molecules with the accumulation of glutathione (GSH), thus protecting the cell from oxidative damage. The gene expression of GST recorded upregulation by about 4-fold and 6-fold for roots and shoots, respectively, with respect to salt-stressed pots (Figure 4c).

Lipases cause alterations in membrane lipid composition; this response induces the formation of toxic lipid intermediates that cause membrane damage or cell death. Unlike all the tested genes, the gene expression of lipase was downregulated at S + I in roots and shoots by $86.7 \%$ and $88 \%$, respectively, compared to salt-stressed eggplants (Figure $4 \mathrm{~d}$ ).

In plants, PGPR can produce cell-wall-degrading enzymes (e.g., proteases) to suppress pathogen growth. In the present study, the gene expression of Prot. I and II was upregulated in inoculated salt-stressed plants with respect to stressed pots. It is to be noted that Prot. I showed higher gene expression upregulation than Prot. II for root and shoot (Figure 4e,f). 

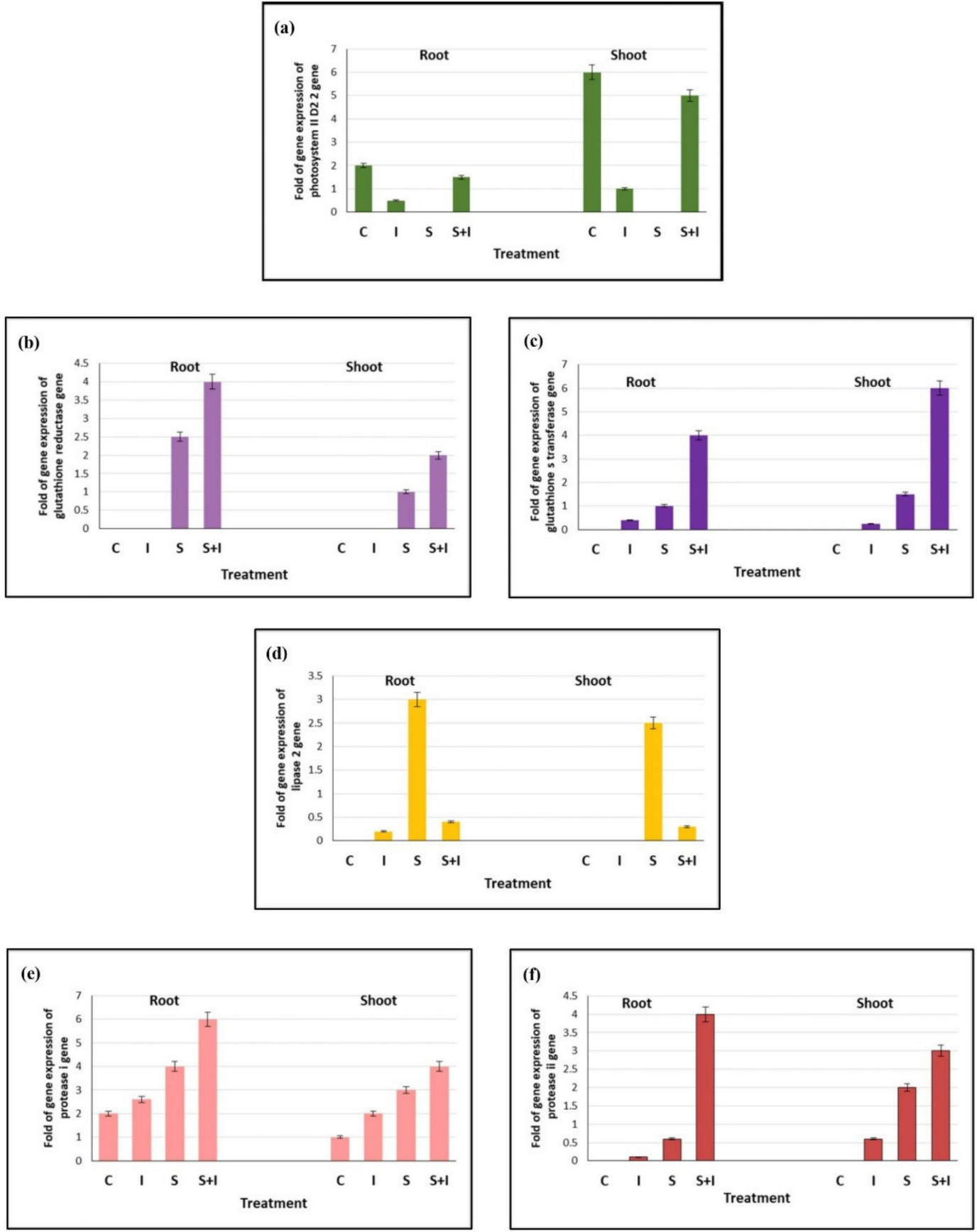

Figure 4. Effect of $0(\mathrm{C})$, selected bioinoculum (I), $200 \mathrm{mM} \mathrm{NaCl}(\mathrm{S})$, and their interactions on the gene expression of PSII D2 (a), glutathione reductase (GR) (b), glutathione S transferase (GST) (c), lipase (d), protease I (e), and protease II (f) in the roots and shoots of S. melongena L. plants 66 days after sowing. Values are means $\pm \mathrm{SE}$ based on triplicate independent determinations.

\section{Discussion}

Solanum melongena $\mathrm{L}$. is an important economic species that exhibits a sensitive response to moderate salinity levels [15].

In the present study, application of $200 \mathrm{mM} \mathrm{NaCl}$ caused a significant decrease to all morphometric growth traits except RL and R/S ratio. Several studies have shown an inhibition in growth parameters and biomass production due to the increase in salinity 
level $[15,16]$. Triticum vulgare exhibited reduction in plant height and total shoot dry weight under $200 \mathrm{mM} \mathrm{NaCl}$-stress [17]. Perica et al. [18] reported that the primary response to salinity stress is expressed by reduction of root and shoot development. In the current work, a relatively insignificant increase in root length accompanied by a significant decrease in shoot length emphasized that shoot growth is more sensitive to salt stress than root. Therefore, an increase in $\mathrm{R} / \mathrm{S}$ ratio is a direct consequence of plants exposure to salinitystress [19].

The applied selected inoculum to salt-stressed plants in the present study caused a significant increase in morphometric traits such as: root and shoot water contents together with fresh and dry weights. As Ha-Tran et al. [20] elucidated, the beneficial impacts of crop plant bacterization with PGPR include inducing plant growth and development and stimulating tolerance to salt stress through different mechanisms. Also, PGPR contributes to salinity stress alleviation in plants by advancing water absorption ability and enhancing essential nutrients uptake [21]. Abd Allah et al. [22] found that the B. subtilis (BERA71)inoculated salt-stressed Cicer arietinum plants yielded higher plant biomass with reduced ROS levels compared to the non-inoculated seedlings. Concomitantly, Khosravi et al. [23] reported that the use of Pseudomonas fluorescens bacterium enhanced shoot dry matter and uptake of different nutrients in Lactuca sativa L.

In the current work, reduction of photosynthetic pigments is another consequence of salinity stress that led to photosynthetic disruption. This finding agreed with the results of Taibai et al. [24] on Phaseolus vulgaris L., and on Vigna subterranean L. [25]. Lower levels of photosynthetic pigment under salt stress were attributed to either slow synthesis or fast degradation of pigments [26]. Nevertheless, the results of all photosynthetic pigments were significantly increased when the selected bioinoculum was applied to salt-stressed plants. Photosynthetic pigments of Gossypium hirsutum were significantly reduced under salinity conditions, however, utilization of salt tolerant bacteria including Bacillus subtilus and Bacillus sp. while producing IAA restored cotton systemic resistance to salt-stress [27]. Analogously, the protective effects of salt tolerant PGPR on photosynthetic pigment were also recorded in Phaseolus vulgaris L. and Arachis hypogaea L. [28]. Azarmi-Atajan et al. [29] reported that inoculating Lactuca sativa L. with strains of Pseudomonas sp. significantly increased chlorophyll and carotenoids content under different salinity levels, enriching soil fertility through the production of hormones, proteins and prolines [30]. This may elucidate the role of the selected bioinoculum in the enhancement of chla, chl b, and carotenoids under salt-stress conditions, as well as suggest that this microbiome can be applied as an effective green biofertilizer under salt-stress conditions.

Insignificant changes in PSII activity expressed by $F_{\mathrm{v}} / \mathrm{F}_{\mathrm{m}}$ and $\mathrm{F}_{\mathrm{v}} / \mathrm{F}_{0}$ in all treatments suggest that the activity of PSII isn't affected by salinity stress. This is supported by four eggplant regenerates that showed an evident stability in tolerating salinity by preserving quite stable $F_{v} / F_{m} C h l$ fluorescence [31]. Similar findings have been attained for salttolerant tomato [32] and wheat [33]. The insignificant increase in Chl fluorescence was accompanied by a significant increase in photosynthetic pigments after microbiome inoculation of salt-stressed plants. Inoculation with Azotobacter chroococcum and application of $\mathrm{Zn}^{2+}$ to Glycine max causes enhancement of chlorophyll $(\mathrm{a}, \mathrm{b}$, and $\mathrm{a}+\mathrm{b})$, carotenoid contents, and $\mathrm{F}_{\mathrm{v}} / \mathrm{F}_{\mathrm{m}}$ ratio [34].

The current work's elemental status revealed that the utilized bioinoculum significantly restricted $\mathrm{Na}^{+}$uptake in the roots of salt stressed plants, with $\mathrm{TF}=0.71$ compared to 0.96 under salt stress. In addition, the decreased $\mathrm{Na}^{+}$uptake was possibly due to a reduced passive (apoplasmic) flow of $\mathrm{Na}^{+}$into the stele as a result of a greater proportion of the root zones being covered with soil sheaths in inoculated treatments [35,36]. However, $\mathrm{K}^{+}$ions and $\mathrm{K}^{+} / \mathrm{Na}^{+}$ratios were increased more in shoots than roots. The favored translocation of $\mathrm{K}^{+}$over $\mathrm{Na}^{+}$from roots to shoots and the greater $\mathrm{K}^{+} / \mathrm{Na}^{+}$ratio in the shoots of inoculated eggplant indicated that selective uptake of $\mathrm{K}^{+}$had occurred, which appears to be one of the processes involved in the tolerance of eggplant to salinity stress. Similar results were detected by Ha-Tran et al. [20] on NaCl-exposed eggplants inoculated with Bacillus brevis. 
Moreover, Bacillus subtilis (BERA 71) stimulates the acquisition of $\mathrm{K}^{+}, \mathrm{Ca}^{2+}, \mathrm{Mg}^{2+}$, and $\mathrm{N}$ in Cicer arietinum, while inhibiting $\mathrm{Na}^{+}$uptake [22].

The significant increase of the selected bioinoculum to $\mathrm{K}^{+}, \mathrm{K}^{+} / \mathrm{Na}^{+}$and $\mathrm{Ca}^{2+}$ revealed that this association collaborated to expel $\mathrm{Na}^{+}$ions. This might be concluded from the perspective mechanism illustrated by El-Dakak et al. [37] involving salt overly sensitive signaling pathway (SOS). Thus, the proposed regulatory mechanism to control salinity stress in eggplant involves the mitigating effect of PGPR and RF through decreasing $\mathrm{Na}^{+}$ and increasing $\mathrm{K}^{+}$as both share a common pump. Thus, $\mathrm{K}^{+} / \mathrm{Na}^{+}$ratio as well as $\mathrm{Ca}^{2+}$ content increased where both have an effective role in expelling $\mathrm{Na}^{+}$through SOS pathways. An increase in $\mathrm{Ca}^{2+}$ content gets perceived by SOS3, which starts the regulation mechanism of ion homeostasis. Then, SOS3 binds to the activated SOS2 [38]. The activated SOS3SOS2 protein complex phosphorylates the SOS1 plasma membrane $\mathrm{Na}^{+} / \mathrm{H}^{+}$antiporter to efficiently pump $\mathrm{Na}^{+}$out of the cell [39].

The slight insignificant increase in $\mathrm{Mg}^{2+}$ ions for shoots of inoculated salt-stressed eggplants was accompanied by a significant increase in photosynthetic pigments. This may be explained by the fact that in the current study, $\mathrm{Mg}^{2+}$ concentration was recorded at $2.75 \mathrm{mg} \mathrm{g}^{-1} \mathrm{DW}$ which might not hamper photosynthesis. In addition, it was reported by Hauer-Jákli and Tränkner [40] that $\mathrm{Mg}^{2+}$ concentrations of less than $1.5 \mathrm{mg} \mathrm{g}^{-1} \mathrm{DW}$ didn't induce negative effects on the photosynthetic capacity of Triticum aestivum and Helianthus annus. In another study, low leaves $\mathrm{Mg}^{2+}$ supply $\left(0.3 \mathrm{mg} \mathrm{g}^{-1} \mathrm{DW}\right)$ did not affect vegetative biomass formation in wheat [41].

Phosphorous and nitrogen were also significantly enhanced in bioinoculated saltstressed eggplants compared with salinity-stressed conditions. This was suggested to be due to the attractive approach of P-solubilizing activity of Bacillus subtilis, Pseudomonas sp., and Aspergillus terreus. Bacillus subtilis solubilizes soil P, enhances nitrogen fixation, and produces siderophores that suppress the growth of pathogens [42]. The Pseudomonas stutzeri strain A1501 fixes nitrogen under microaerobic conditions in the free-living state where certain gene products in this species are involved in the regulation of the nitrogen fixation process. Interestingly, A. terreus strains were able to solubilize zinc-P under very saline conditions (up to $10 \% \mathrm{NaCl}$ ) [43].

Solanum melongena as glycophyte restricts toxic ions intake by roots and constrains their transport to the shoot. In the current study, under salinity stress $\mathrm{Na}^{+}$ions were largely translocated to the shoot; this was revealed from the relatively higher TF compared to that of untreated plants, while application of selected bioinoculum to salt-stressed eggplants relatively decreased the TF of $\mathrm{Na}^{+}$ions with respect to saline pots. The Solanum trovum resistance mechanism to salinity was moderately based on the active transport of toxic ions to the leaves and, probably, a better capacity to store them in the vacuoles $[44,45]$.

Polyamines are documented to enhance plants stress tolerance, however, PGPR secretion of polyamines is largely unknown [46]. Application of the selected bioinoculum to salt-stressed eggplants in the current work showed a significant increase of both root and shoot tested Spm and Spd compared to salt stressed plants. The shoot attained relatively higher PAs than the root, suggesting production of hormonal signals from the root that communicates information to the shoot. The higher level of root Put compared to Spm + Spd revealed its substantial alleviative role in defending against salt-stress in eggplant roots. Because of the polycationic nature of polyamines, they participate with antioxidant activity and scavenging free radicals in plant salt tolerance strategies to abiotic stresses [47]. Concomitantly, Zhang et al. [48] emphasized Put effect on enhancing salt tolerance by reducing the oxidative damage in Glycine max L. roots. The exogenous Put might be closely related to salt stress tolerance in plants, which inhibits $\mathrm{Na}^{+}$uptake and stimulates $\mathrm{K}^{+}$ inward, thus increasing the $\mathrm{K}^{+} / \mathrm{Na}^{+}$ratio in cucumber [49]. Current data showed that the increase in endogenous root Put exerted the same effect on $\mathrm{Na}^{+}, \mathrm{K}^{+}$, and $\mathrm{K}^{+} / \mathrm{Na}^{+}$ratio.

Nevertheless, the shoot Spm + Spd of the studied eggplant exceeded Put by about 7-fold suggesting their substitutive role in shoot salt tolerance. Zapata et al. [50] recorded an increased ratio of $(\mathrm{Spm}+\mathrm{Spd}) /$ Put under salinity that has been correlated with the 
defensive role against salt-stress. Similarly, El-Shintinawy [51] also referred that salinity significantly boosted the increase of Spm and Spd accompanied with an inhibition in Put content in Triticum aestivum L. cultivars. Xie et al. [52] reported that Bacillus subtlilis OKB105 synthesized spermidine and is the pivotal compound related to plant growth promotion. Additionally, Spermidine from Bacillus megaterium BOFC15 increased cellular polyamine accumulation in Arabidopsis, thereby activating PA-mediated signaling pathways contributing to the osmotic stress tolerance of plants [46].

Accumulation of proline is a common feedback to salt stress in crop plants. In the current study, under salinity stress, proline content recorded a significant increase in roots and shoots compared to control. Proline content was increased in two genotypes (Barcelone and Threa) of S. melongena L. under salinity stress [53]. Similarly, leaf proline levels increased significantly in S. melongena and S. insanum in response to different salt stress treatments, moreover it is suggested that $S$. insanum is more tolerant to salinity stress due to its capacity to accumulate proline and to a lesser extent $\mathrm{Na}^{+}$and $\mathrm{Cl}^{-}$[44].

Application of the bioinoculum to salt stressed eggplants resulted in higher proline content for roots and shoots, which was consistent with the substantial enhancement of proline after inoculation of Oryza sativa with nine salt tolerant bacterial isolates including Bacillus sp. [54]. This clarifies the mitigating role of proline in the defense system of eggplants through sweeping ROS, adjusting ion homeostasis, protecting osmotically, and stabilizing subcellular structures. Interestingly, it seems to be a cooperative role between proline and polyamines to alleviate salinity stress in roots and shoots of S. melongena L. as both attained increasing contents at S + I compared to salt-stressed pots, at least in the presented dataset under the prevailing experimental conditions.

Molecular characterization of the gene expression using RAPD PCR reveals some of the physiological defensive mechanisms. The expression of psbD gene encoding the D2 subunit of the PSII reaction center (PSII D2 protein) is particularly interesting, because D2 represents the starting point for the assembly of PSII as a whole [55]. In the current work, the upregulation of the shoot psbD gene expression by about 5-fold was achieved after treatment of salt-stressed eggplants with the selected bioinoculum. This refers to the efficiency of binding to cofactors and the effectiveness of electron transfer through D2 protein that constitutes part of the D1-D2 heterodimer of PSII; consequently, it signifies the efficiency of PSII in ATP formation. The amount of D2 available directly determines the levels of the other component subunits of PSII via feedback control mechanisms according to the CES model (control by epistasis of synthesis) for the temporal sequence of PSII assembly [56]. As well, mycorrhizal colonization of salt stressed Robinia pseudoacacia upregulated the expression of three chloroplast genes, including RppsbD in leaves [57].

The activity of GR is reported to play a pivotal role in determining stress tolerance in plants under different abiotic stresses [58]. The upregulation of GR gene expression in eggplant roots and shoots confirmed that, as a consequence of PGPR and RF inoculation, eggplant acquired protection against challenging salt stress. These results agree with the study of Gururani et al. [59], who documented the enhanced mRNA expression of different ROS pathway genes after exposure to salt, drought, and heavy metal stress in PGPR inoculated Solanum tuberosum plants. Also, inoculating Abelmoschus esculentus L. plants with PGPR, including Bacillus megaterium and Enterobacter sp. resulted in the upregulation of ROS pathway genes (APX, CAT, DHAR, and GR) under salinity stress [60]. Moreover, in a study by Brenes et al. [44], results of semiquantitative RT-PCR revealed that expression levels of different ROS pathway genes encoding APX, CAT, GR, and DHAR were increased in the ACC deaminase-containing PGPR treated salinized plants compared to the untreated controls.

Various environmental stimuli enhanced the expression of GST, including biotic stresses such as fungal elicitors and pathogen attack [61], and abiotic stresses such as salt [62] and drought [63]. The gene expression of GST in the currently studied salt-treated eggplants inoculated with PGPR and RF was upregulated 4-fold in salt-treated pots. Trehalose metabolite application derived from PGPR improved glutathione-S-transferase 
(GST), CAT, APX, and DHAR activities, and stimulated the glyoxalase network [64]. Analysis of Arabidopsis cell-suspension culture suggested early stress-induced changes in the expression of genes with the involvement of GST in oxidative stress protection [65]. Similarly, GmGSTU4-expressing transgenic tobacco plants provided tolerance to salt stress and the herbicide alachlor [66].

Different types of abiotic stress, including salinity, induce lipid remodeling through specific lipases that form toxic lipid intermediates, causing membrane damage or cell death $[67,68]$. Nevertheless, in the current study, downregulation of lipase gene expression for salt-stressed eggplants treated with bioinoculum confirmed the mitigating role of PGPR and RF of salt stress through the integrity of lipid constituents of the cell membrane. Singh and Jha [69] discovered that treating salt-stressed wheat plants with the Serratia marcescens bacterium efficiently scavenged ROS, resulting in lower levels of lipid peroxidation and membrane injury. It was reported in a study by Cook et al. [70] that lipases play a pivotal role in oxylipins synthesis, thus lipases specific to lipids of thylakoids confer in environmental stress response. Therefore, it has been suggested to focus on the role of lipases under different environmental stresses to better understand the physiological regulatory mechanisms involved.

Control of pathogenic diseases can be generated by PGPR extracellular secretion of proteases that hydrolyze other microbial cell walls, and trigger induced systemic resistance against pathogenic infection in plants [71]. Thus, in the current work, the exposure of saltstressed eggplants to the selected bioinoculum caused the production of two proteolytic enzymes (prot. I and prot. II) with higher upregulation of prot. I than prot. II in both roots and shoots. This suggests that the biocontrol of PGPR and RF as biopesticides against infectious pathogens could enhance the systemic resistance of eggplants. Aminisarteshnizi [72] emphasized that the growth-promoting bacterium Pseudomonas fluorescens produces a lytic enzyme protease that suppresses the root-knot pathogen nematode Meloidogyne incognita in eggplant crops. In addition to inhibiting penetration and consequent root-knot infection in Vigna radiata [73], Bacillus subtilis strain and Pseudomonas aeruginosa caused more than $50 \%$ mortality of juveniles of the root-knot nematode Meloidogyne javanica. Also, an isolated strain of Bacillus subtilis was recorded to induce systemic resistance against powdery mildew on barley [74]. In a study by Behera et al. [75], the two fungal isolates Trichoderma longibrachiatum and Penicillium rubidurum were able to produce a proteolytic zone of the alkaline protease. Moreover, many fungal species of the genera Aspergillus, Trichoderma, Rhizopus, Mucor, and Penicillium have been documented for protease production [76].

The PGPR and RF selected in the current work suggest a modulatory impact on the systemic resistance of Solanum melongena L. Baldi cultivar to challenging salt stress, which strongly recommends their application as an effective green biofertilizer and biopesticide. Systemic resistance begins with plant genes until morphometric traits (Figure 5). Resistance originates from gene expression related to four of the most treasured physiological aspects in plants, photosynthesis, the antioxidant system, and the catabolism of lipids and proteins. Thus, the collaboration of these genes was reflected in the biochemical constituents in roots and shoots, and sometimes leaves. It seems that $\mathrm{psbD}$ enhances photosynthetic pigments and the efficiency of PSII $\left(\mathrm{F}_{\mathrm{v}} / \mathrm{F}_{\mathrm{m}}\right.$ and $\left.\mathrm{F}_{\mathrm{v}} / \mathrm{F}_{0}\right)$ with no significant change among all treatments. Osmoprotection and antioxidant systems to ROS formed under salinity stress are scavenged and controlled by GR and GST, which might have a role in increasing proline and polyamines content. Elemental homeostasis contributes to either restricting or expelling $\mathrm{Na}^{+}$ions via the SOS signaling pathway. Catabolism of lipids contributes to preserving the compartment cell membrane while defending against pathogenic diseases and is achieved by lytic proteases. Finally, this was expressed in the morphology and morphometric traits of Solanum melongena L. plants. 


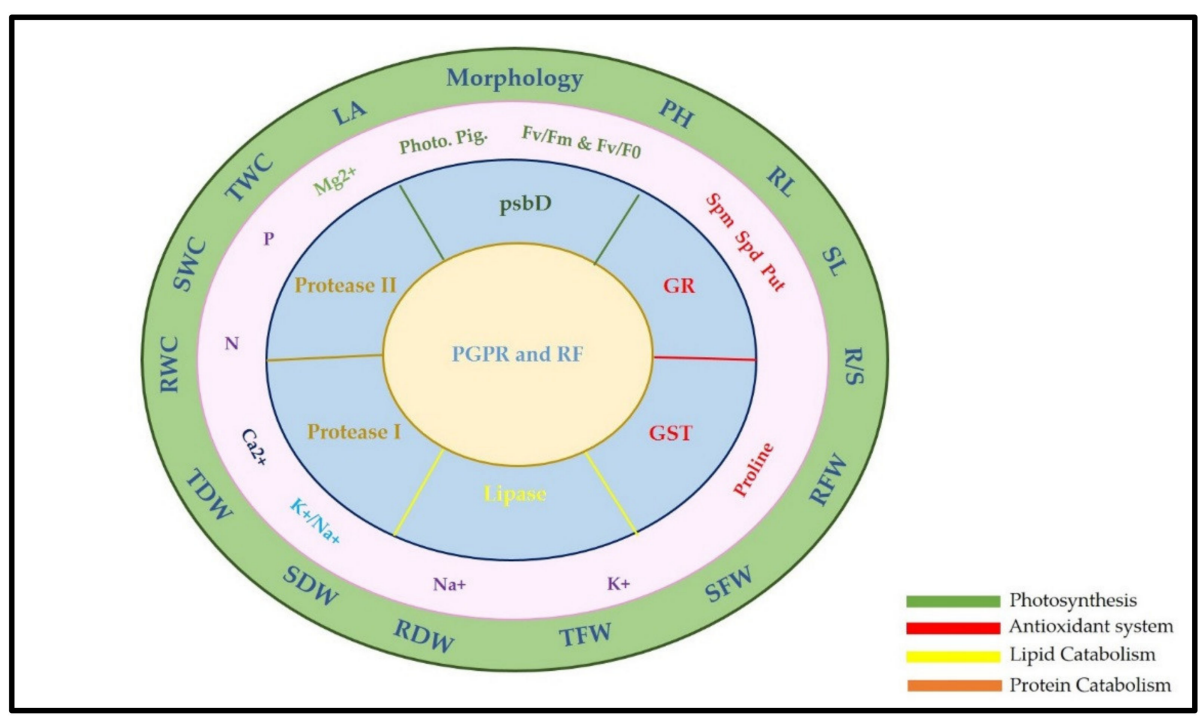

Figure 5. Proposed modulation of systemic resistance in salt-stressed Solanum melongena L. shoots and roots due to inoculation with selected PGPR and RF. Colored box refers to physiological aspects; psbD related to photosynthesis in green; GR and GST related to antioxidant system in red; lipase related to lipid catabolism in yellow; protease I and protease II related to protein catabolism in brown.

\section{Materials and Methods}

\subsection{Experimental Materials and Growth Conditions}

A pure variety of eggplant seeds (Solanum melongena L. Baladi) cultivar was obtained from Nubaseed Company. Viable seeds of eggplant were surface sterilized with $0.1 \%(v / v)$ $\mathrm{HgCl}_{2}$ solution for $5 \mathrm{~min}$ and then rinsed three times with distilled water. Seeds were soaked in distilled water for 5 days to break dormancy until they radically began to rise a few $\mathrm{mm}$ in length. Early germinated seeds (EGS) were translocated to a styrofoam seedling tray. The soil mixture used in all experiments was composed of (clay: sand; 1:2). The styrofoam seedling tray was watered twice a week with distilled water till the first foliage leaf appeared (14 days after sowing "DAS").

\subsection{Isolation and Identification of Plant Growth Promoting Rhizobacteria and Rhizofungi}

Strains of PGPR as well as RF were isolated from the rhizospheric soil of S.melongena L. Baladi cultivar grown in saline soil. In experiments conducted as part of the current study, two strains of PGPR (Bacillus subtilis B1ZSRS and Pseudomonas sp. B2ZSRS) and three strains of rhizofungi (RF) (Trichoderma harzianum, Aspergillus terrus, and Penicillium citrinum) were used as test inoculum.

\subsubsection{Differentiation between Bacterial Isolates}

RAPD PCR was developed in recent years to describe and indicate the phylogeny of different organisms. The chosen bacterial isolates were subjected to RAPD PCR utilizing A and $C$ short primers; their sequences are A: AGGAGGACACTATGAGTG and C: TACGGYACCTTGTTACGACTT. The cyclic reaction, composed of $4 \mathrm{~min}$ at $95{ }^{\circ} \mathrm{C}$ and then 40 cycles of $40 \mathrm{~s}$ at $94{ }^{\circ} \mathrm{C}, 50 \mathrm{~s}$ at $30^{\circ} \mathrm{C}$, and $50 \mathrm{~s}$ at $72{ }^{\circ} \mathrm{C}$, followed by a supplementary $10 \mathrm{~min}$ at $72{ }^{\circ} \mathrm{C}$ [77]. Primer $\mathrm{C}$ more effectively differentiated selected bacterial isolates than primer A. For all isolates tested, the size of the amplified PCR fragment was estimated; the primers will bind somewhere in the structure, but it is unknown exactly where. Three bacterial isolates, B1, B4, and B7 were subjected to further study and identification.

\subsubsection{Molecular Identification and Phylogeny of Bacterial Isolates}

A Thermo Fisher's kit was used to extract genomic DNA. The universal primers were used to amplify the $16 \mathrm{~S}$ rRNA region (F: AGAGTTTGATCMTGGCTCAG and R: TACGGYACCTTGTTACGACTT) [78]. The reaction was carried out with the aid of a DNA 
template. The MEGA 7 software tool was used to perform several alignments based on the most closely related sequences and similarity values. The MEGA 7 program was used to rebuild a phylogenetic tree.

\subsubsection{Identification of Fungal Strains}

The three fungal strains used in the applied bioinoculum were identified at the mycological center in the faculty of science at Assuit University, Egypt. The fungal cultures were grown in sterile Petri plates containing autoclaved Czapek's yeast extract agar (CYA) followed by incubation for 7 days at $28^{\circ} \mathrm{C}$ [79]. The medium contained (g/L): sucrose, 30; $\mathrm{Na}_{2} \mathrm{NO}_{3}, 2 ; \mathrm{K}_{2} \mathrm{HPO}_{4}, 1 ; \mathrm{KCl}, 0.5 ; \mathrm{MgSO} 4.7 \mathrm{H}_{2} \mathrm{O}, 0.5 ; \mathrm{FeSO}_{4}, 0.01 ; \mathrm{ZnSO}_{4}, 0.01 ; \mathrm{CuSO}_{4}, 0.005 ;$ yeast extract 5; chloramphenicol, 0.25; and agar, 15 (final pH 7.3). Identification of the growing fungi was based on colony characteristics (growth rate, color, texture, and reverse pigmentation) as well as microscopic features (shape of conidiophores, conidiogenous cells, and conidial dimensions). Fungal hyphae and conidia were stained with lactophenol cotton blue for better visualization. An Axiostar trinocular microscope, made by Zeiss in Germany, was used for the examination. The main references consulted for identification included [80-82].

\subsection{Characterization of the Selected Plant Growth Promoting Bacteria and Rhizofungi}

Table 4 gives an insight into different bacterial and fungal species constituting the selected bioinoculum applied to the $S$. melongena Baldi cultivar exposed to salinity stress in the present study.

Table 4. Microbial load (bioinoculum I) characterization applied on Solanum melongena L. after exposure to $200 \mathrm{mM} \mathrm{NaCl}$ salinity stress.

\begin{tabular}{|c|c|c|c|c|}
\hline Organism & $\begin{array}{l}\text { Type of } \\
\text { Organism }\end{array}$ & $\begin{array}{l}\text { Location of the } \\
\text { Organism }\end{array}$ & Function of the Organism & Reference \\
\hline Bacillus subtilis & $\begin{array}{l}\text { Gram + ve } \\
\text { non- } \\
\text { pathogenic } \\
\text { Bacterium }\end{array}$ & $\begin{array}{l}\text { Soil/Colonizing } \\
\text { plant roots }\end{array}$ & $\begin{array}{c}\text { * Salt tolerant bacterium } \\
\text { * Protect cellular membranes integrity } \\
\text { * Increase nitrate reductase and glutamine synthetase activities } \\
\text { * Supply IAA to the cultures } \\
\text { * Reduce ethylene generation under salt stress through ACC } \\
\text { deaminase secretion, thus increase nutrient uptake and growth. } \\
\text { * Decrease oxidative and osmotic induced stress } \\
\text { * Manifested plant growth improvement, slowing down statolite } \\
\text { starch hydrolysis under salinity }\end{array}$ & {$[4,83-86]$} \\
\hline Pseudomonas sp. & $\begin{array}{l}\text { Gram -ve } \\
\text { Bacterium }\end{array}$ & $\begin{array}{l}\text { Saprophytic/ } \\
\text { parasite on plant } \\
\text { surfaces }\end{array}$ & $\begin{array}{l}\text { * Salt tolerant bacteria } \\
\text { * Promote plant growth by suppressing pathogenic micro-organisms } \\
\text { * Synthesize growth-stimulating plant hormones } \\
\text { * Promote increased plant disease resistance } \\
\text { * Salt tolerant fungi }\end{array}$ & [87-89] \\
\hline $\begin{array}{l}\text { Trichoderma } \\
\text { harizanum }\end{array}$ & $\begin{array}{l}\text { Free-living } \\
\text { saprophytic } \\
\text { fungi }\end{array}$ & $\begin{array}{l}\text { In most types of } \\
\text { soils/mutualistic } \\
\text { endophytic with } \\
\text { plant species }\end{array}$ & $\begin{array}{l}\text { * Significantly suppress the growth of plant } \\
\text { pathogenic microorganisms } \\
* \text { Regulate the rate of plant growth } \\
* \text { Well known for biological control mechanism } \\
* \text { Produce secondary metabolites in agroecosystems }\end{array}$ & [90-92] \\
\hline $\begin{array}{l}\text { Aspergillus } \\
\text { terrus }\end{array}$ & $\begin{array}{c}\text { Saprophytic } \\
\text { filamentous } \\
\text { fungi }\end{array}$ & $\begin{array}{l}\text { Part of the soil } \\
\text { microbiota/can be } \\
\text { found in many } \\
\text { types of } \\
\text { soils/frequently } \\
\text { found as endophytic }\end{array}$ & $\begin{array}{c}\text { * May live at } \mathrm{pH} 3 \text { and } 30 \% \text { salinity } \\
\text { * Used with PGPR, induces positive effects on plant growth } \\
\text { and development } \\
\text { * Induce systemic resistance and reduce plant stress } \\
* \text { Attain phosphorous-solubilizing activity } \\
{ }^{*} \text { Strong biocontrol activity }\end{array}$ & [93-95] \\
\hline $\begin{array}{l}\text { Penicillium } \\
\text { citrinum }\end{array}$ & $\begin{array}{l}\text { Mesophilic } \\
\text { Fungus }\end{array}$ & $\begin{array}{c}\text { Soil is their natural } \\
\text { habitat }\end{array}$ & $\begin{array}{c}\text { * Isolates tolerate salt concentration above } 10 \% \\
\text { * Plant growth promoting ability } \\
\text { * Contain ACC deaminase activity which sustains plant growth and } \\
\text { development under stress conditions } \\
\text { * Produces mycotoxin citrinin, cellulase, endoglucanase, as well } \\
\text { as xylulase. } \\
\text { * Produces Gibberellins }\end{array}$ & {$[8,96,97]$} \\
\hline
\end{tabular}




\subsection{Experimental Design}

The experiments of the current study were carried out as factorial experiments based on Randomized Complete Block Design, with three replications in the Botanical Garden at the Faculty of Science, Alexandria University, Egypt. A sublethal concentration of $200 \mathrm{mM}$ $\mathrm{NaCl}$ was determined after preliminary salinity screening of $30-300 \mathrm{mM} \mathrm{NaCl}$ on Solanum melongena $\mathrm{L}$.

The tested inoculum (2 PGPR X $3 \mathrm{RF}$ ) was selected based on prior permutations and combinations using Minitab (version 12) for different PGPR and RF strains that have been isolated from S. melongena as previously mentioned. The tested isolates were purified, identified, and numbered, then preserved on $50 \%$ glycerol stock. Biochemical analysis of isolated PGPR and RF was carried out before identification.

Selection of the tested inoculum applied in the current work on S. melongena under salinity stress was based on the best morphological parameters measured and the leaves proline content from a preliminary experiment (Supplementary Table S1).

The experiments were carried out under controlled conditions (photon flux density (PFD) of $450 \mu \mathrm{mol} \mathrm{m}{ }^{-2} \cdot \mathrm{s}^{-1}, 14 / 10 \mathrm{~h}$ light/dark cycle, temperature of $30 \pm 5{ }^{\circ} \mathrm{C}$ and relative air humidity of about $85 \%$ ). After sowing, the field capacity of the culture pots was estimated at $450 \mathrm{~mL}$ of demineralized water. Experiments were carried out using a homogenous dried soil mixture in plastic culture pots $(12 \mathrm{~cm}$ diameter and $30 \mathrm{~cm}$ height with $1 \mathrm{~kg}$ soil capacity. In each pot, two selected seedlings from the styrofoam seedling tray of S. melongena were planted (14 DAS). Pots were regularly irrigated to field capacity three times/week during the whole experiment. Planted pots were left for 9 days to acclimatize to pot conditions, and on day 9 , pots were supplied with $1 / 4 \mathrm{~N}$ Hoagland solution. The first half of the pots received distilled water (30 DAS), while the second half received $200 \mathrm{mM} \mathrm{NaCl}$ until wilting symptoms appeared. All pots were exposed to optimized closed growth chambers.

There were 40 pots for each experimental unit (replicate), with 2 plants/pot. The pots were divided into four sets (47 DAS) with 20 plants/set; one irrigated with distilled water I; the second one inoculated with the selected inoculum and irrigated with distilled water (I); the third set was irrigated with $200 \mathrm{mM} \mathrm{NaCl}$ (S); and the fourth set was irrigated with $200 \mathrm{mM} \mathrm{NaCl}$ and inoculated with selected inoculum (S + I). Eggplant samples were harvested 66 days after sowing, washed with running tap water, followed by demineralized water, then blotted gently using layers of tissue paper.

\subsection{Measurement of Growth Traits}

Different growth traits were determined in shoots and roots at the end of the salt treatments: plant height $(\mathrm{PH})$, root length (RL), shoot length (SL), R/S ratio, and fresh weight of root and shoot systems were immediately determined. Dry weight samples were dried at $80^{\circ} \mathrm{C}$ till a constant dry weight was reached. The salt-tolerance index (STI $\%)$ for different treatments was calculated as the percentage of the ratio of the value for the $\mathrm{NaCl}$-treated plant/value for the control [98]. STI was calculated for all measured growth traits.

The Leaf Area Meter, a Model LI 3000 Portable Area Meter assembled with a conveyor belt, was used to calculate leaf area. Individual areas were measured to the nearest square centimeter.

\subsection{Extraction and Estimation of Chlorophyll and Carotenoid Contents}

According to the method of Lichtenthaler et al. [99], the content of chlorophyll and carotenoids were determined. Solanum melongena leaves fresh weight (100 mg FW) was blotted dry on tissue paper and placed in $5 \mathrm{~mL}$ of di-methyleformamide, left to stand in the dark over night for complete extraction. Absorbance was recorded at $646.8 \mathrm{~nm}$ and $663.2 \mathrm{~nm}$ for the chlorophyll assay and $453 \mathrm{~nm}$ for the carotenoids assay (in the supernatant) by a UV-Visible spectrophotometer (JENWAY, 6305, Staffordshire, ST15 OSA, UK). 


\subsection{Measurement of Chlorophyll Fluorescence}

Chlorophyll fluorescence measurements were monitored in fully expanded young leaves. Measurements of $\mathrm{Chl}$ fluorescence were performed with the OS-30P pulse modulated chlorophyll fluorimeter (Opti-sciences, Hudson, NY, USA). Fluorescence was excited by illuminating leaves with a wear, red pulsed measuring light intensity $\left(<0.1 \mu \mathrm{mol} \mathrm{m}{ }^{-2} \mathrm{~s}^{-1}\right)$ with a peak wavelength of $650 \mathrm{~nm}$. Prior to measurement of fluorescence, plants were kept in darkness at $22 \pm 2{ }^{\circ} \mathrm{C}$ for at least $40 \mathrm{~min}$ to allow dark adaptation to ensure that the primary quinine acceptor (QA) was maximally oxidized. The basal non-variable chlorophyll fluorescence level with open PII reaction centers $\left(\mathrm{F}_{\mathrm{o}}\right)$ and the maximal fluorescence intensity indicator $\left(\mathrm{F}_{\mathrm{m}}\right)$ level with closed PSII were determined at room temperature on intact leaves of 10 replicate plants from all treatments. The $F_{o}$ (as initial fluorescence level) was measured by a weak red measuring beam, followed by a saturation light pulse to measure the maximum $\mathrm{F}_{\mathrm{m}}$ level. The variable fluorescence $\left(\mathrm{F}_{\mathrm{v}}\right)$ was calculated as the difference between $F_{m}$ and $F_{o}$. The maximum quantum yield of PSII $\left(F_{v} / F_{m}\right)$ was also calculated [100].

\subsection{Elements Analysis}

Sample preparation, metal analysis, and quality control were carried out according to the standard method of Kimbrough and Wakakuwa [101]. Oven-dried and homogenously milled, $200 \mathrm{mg}$ of plant samples were mixed with $3 \mathrm{~mL}$ of concentrated $\mathrm{HNO}_{3}$ in a beaker and covered with a ribbed watch glass. Then, the mixture was heated on a hot plate at $90-95{ }^{\circ} \mathrm{C}$ and left to evaporate to a low volume. After cooling, the previous step was repeated with additional portions $(3 \mathrm{~mL})$ of $\mathrm{HNO}_{3}$ until the digested solution either turned into a lighter color or reached a stable color, and the digestate was then refluxed with a small portion of $\mathrm{HCl}(3 \mathrm{~mL})$ for complete digestion. Finally, the sample was filtered through filter paper (Whatman 42, diameter $110 \mathrm{~mm}$ ). Then, the beaker walls and watch glass were washed with deionized water, and the filter paper was rinsed with diluted HNO3 (10\%). The final volume was adjusted to $25 \mathrm{~mL}$ with deionized water. To determine different metal contents, the solutions were subjected to Inductively Coupled Plasma-Optical Emission Spectroscopy (ICP-OES; Agilent 5100 VDV, Santa Clara, CA, USA). The content of $\mathrm{Na}^{+}$, $\mathrm{K}^{+}, \mathrm{Ca}^{2+}$, and $\mathrm{Mg}^{2+}$ was computed as $\mathrm{mg} \cdot \mathrm{g}^{-1}$. The flow rates of plasma, auxiliary, and nebulizer of ICP-OES were kept at 12,1 , and $0.7 \mathrm{~mL} \cdot \mathrm{min}^{-1}$, respectively. The sample uptake and stabilization time were $10 \mathrm{~s}$ for each sample.

\subsection{Polyamines Detection}

Detection of free polyamines (spermine, spermidine, and puterscine) in S. melongena L. shoots and roots were carried out according to the method described by Gong and Liu [102] using HPLC Amens 2/001.

\subsection{Differential-Display Reverse Transcription-PCR (DDRT-PCR) and Semi Quantitative Gene Expression}

\subsubsection{RNA Extraction}

The frozen plant tissue was transferred to an appropriately sized RNase-free tube. The Easy-spin $^{\mathrm{TM}}$ Total RNA Extraction Kit was used to extract total RNA from plant tissue. A High-Capacity cDNA Reverse Transcription Kit was used for the generation of the first cDNA strand.

\subsubsection{RAPD-PCR}

Twelve short primers specific for photosystem II D2, glutathione reductase (GR, EC 1.6.4.2), glutathione-S-transferase, lipase, protease I, and protease II genes designed using sequences in the gene bank were subjected to PCR for cDNA amplification (Table 5). The resulting patterns were analyzed using a statistical method to determine the molecular weight of different bands that appeared on the agarose gel. PCR reaction was performed for $4 \mathrm{~min}$ at $95{ }^{\circ} \mathrm{C}$ followed by 40 cycles each of: $40 \mathrm{~s}$ at $94{ }^{\circ} \mathrm{C}, 50 \mathrm{~s}$ at $30{ }^{\circ} \mathrm{C}$, and $50 \mathrm{~s}$ 
at $72{ }^{\circ} \mathrm{C}$, followed by a supplementary $10 \mathrm{~min}$ at $72{ }^{\circ} \mathrm{C}$. After amplification by PCR, the products were checked on $2 \%$ agarose gel electrophoresis. Bands which give molecular weight specific to each gene were compared to all treatments (root and shoot) and semiquantitative analysis was carried out using software of gel analyzer (Syngene Geneflash Gel Documentation). A confirmation test was done for the specific PCR product under molecular weight related to the gene after purification using a gel extraction purification kit using the pair of primers that related to the gene under test. A PCR reaction was performed for $4 \mathrm{~min}$ at $95^{\circ} \mathrm{C}$ followed by 40 cycles each of: $40 \mathrm{~s}$ at $94{ }^{\circ} \mathrm{C}, 50 \mathrm{~s}$ at $55^{\circ} \mathrm{C}$, and $50 \mathrm{~s}$ at $72{ }^{\circ} \mathrm{C}$, followed by a supplementary $10 \mathrm{~min}$ at $72{ }^{\circ} \mathrm{C}$ using pairs of primers for specific gene(s) (Table 5). After converting nucleotide sequences to amino acid sequences, sequence data were analyzed and compared with data from a gene bank using different bioinformatics programs (Tcoffee and BioEdit).

Table 5. Primers used for the cDNA amplification to detect photosystem II D2 (psbD), glutathione reductase (GR), glutathione-S-transferase (GST), lipase (Lip.), protease I (Prot. I), and protease II (Prot. II).

\begin{tabular}{ccc}
\hline Primer Sequence & Length $(\mathbf{b p})$ & Gene \\
\hline $\begin{array}{c}\text { F: AGGCTGTGGACCGACATCTA } \\
\text { R: GCTCATGAACACGTCCCTCT }\end{array}$ & 266 & psbD \\
\hline $\begin{array}{l}\text { F: CACATCCTGATCGCCACCG } \\
\text { R: TCCTTCCTGAAGCACAGGTC }\end{array}$ & 200 & GR \\
\hline $\begin{array}{l}\text { F: GAAGATCCCCGTGCTGATCC, } \\
\text { R: AAGTTGGGGAACTTCTCGCT }\end{array}$ & 390 & GST \\
\hline $\begin{array}{l}\text { F: GCACATCCTGAGGGTGAACA } \\
\text { R: AGCTCGTAGTCCTCCCTGTC }\end{array}$ & 369 & Lip. \\
\hline $\begin{array}{l}\text { F: AGGCTGTGGACCGACATCTA, } \\
\text { R: GCTCATGAACACGTCCCTCT }\end{array}$ & 489 & Prot. I \\
\hline $\begin{array}{l}\text { F: CGACACCATGCAGTACGTGA, } \\
\text { R: TGGCGTAGTTGGCGTACATC }\end{array}$ & 386 & Prot. II
\end{tabular}

\subsection{Statistical Analysis}

A two-way analysis of variance (ANOVA) approach was used to analyze the obtained data. Duncan's multiple comparison range tests using SPSS software [103] were carried out to identify statistically significant differences among the treatments at $p<0.05$. Data were presented as means \pm standard deviation $(n=3)$, with different alphabetical letters revealing significant differences between treatments. Student $t$-test was used for normally distributed quantitative variables to compare between two studied groups. "**" means statistical significance at $p \leq 0.05$. The translocation factor (TF) of elements in plants was calculated by dividing the element content in shoots by the element content in roots [104]. Statistical analysis software followed the methods of Sokal and Rohlf [105].

\section{Conclusions}

Most of the studies emphasize the role of plant growth promoting rhizobacteria against biotic and abiotic stresses. Nevertheless, the current study revealed the synergistic effects between rhizofungi and PGPR in salt-stress mitigation, which surprisingly enhance pathogenic disease resistance concomitant with inherent systemic resistance in Solanum melongena L. The ameliorative role of polyamines was depicted in enhancing resistance in eggplant roots and shoots; as putrescene was activated to defend root salinity stress, it was substituted by spermine and spermidine in shoot salt resistance. Further studies are suggested to elucidate the PAs signaling communication for plant-bioinoculum crosstalk. Molecular examination at the gene level untangled the systemic resistance of $S$. melongena to salt-stress with different physiological aspects, which necessitates more investigation to unravel the physiological mechanisms and pathways involved. Thus, the Solanum 
melongena L. Baldi cultivar could be regarded as a source of "salt-tolerance" genes for the genetic improvement of this trait in other eggplants. In particular, improvement of almost all eggplant measured parameters was achieved through PGPR and RF inoculation after 17 days of exposure to $200 \mathrm{mM} \mathrm{NaCl}$ (until wilting). Future application of concomitant inoculum with salt stress predicts much more improvement, as this mimics the probability of further saline water irrigation in agricultural fields. The experiments conducted to test the efficiency of rhizobacteria and rhizofungi revealed that the applied bioinoculum is attractive as well as an economic approach for sustainable agriculture. In the new climate change scenario, there is a need to lower the use of chemical fertilizers. Thus, the abrupt shift towards the environmentally safe, more productive use of natural biofertilizers to reduce pest attacks is a demand of time. Therefore, it is recommended to be addressed in open field conditions to save eggplant as one of the most important economic crops worldwide. Furthermore, it is not just a biofertilizer to counteract salt-noxious effects, but it also acts as a biopesticide due to fungal resistance to pathogenic diseases. The agricultural world is now eager for such types of associations to be applied to further economically important crop plants.

Supplementary Materials: The following supporting information can be downloaded at https: / / www.mdpi.com/article/10.3390/plants11050659/s1, Table S1: Effect of 0 (C), selected bioinoculum (I), $200 \mathrm{mM} \mathrm{NaCl}(\mathrm{S})$ and their interactions on plant height (PH), root length (RL), shoot length (SL), root/shoot ratio (R/S), root fresh weight (RFW), shoot fresh weight (SFW), total fresh weight (TFW) of Solanum melongena L. plant 66 days after sowing; Table S2: Effect of 0 (C), selected bioinoculum (I), $200 \mathrm{mM} \mathrm{NaCl}$ (S) and their interactions on root dry weight (RDW), shoot dry weight (SDW), total dry weight (TDW), root water content (RWC), shoot water content (SWC), total water content (TWC), and leaf area(LA) of Solanum melongena L. plant 66 days after sowing; Table S3: Similarity percentages and accession numbers obtained after comparing the sequence of the tested strain (B1SRZS) to the submitted sequences in Gene Bank; Table S4: Similarity percentages and accession numbers obtained after comparing the sequence of the tested strain (B4SRZS) to the submitted sequences in Gene Bank; Table S5: Similarity percentages and accession numbers obtained after comparing the sequence of the tested strain (B7SRZS) to the submitted sequences in Gene Bank.

Author Contributions: Conceptualization, Z.O., R.E.-D., S.M.; methodology, Z.O., R.E.-D., S.A., S.M.; software, S.A., S.M.; validation, Z.O., S.M.; formal analysis, R.E.-D., S.A., S.M.; investigation, Z.O., R.E.-D., S.A., S.M.; resources, R.E.-D., S.M.; data curation, Z.O., R.E.-D., S.A., S.M.; writing-original draft preparation, R.E.-D., S.M.; writing—review and editing, Z.O., R.E.-D., S.M.; visualization, Z.O., R.E.-D., S.M.; supervision, Z.O., R.E.-D. All authors have read and agreed to the published version of the manuscript.

Funding: This research received no external funding.

Institutional Review Board Statement: Not applicable.

Informed Consent Statement: Not applicable.

Data Availability Statement: The data presented in this study are available on request from the corresponding author.

Conflicts of Interest: The authors declare that they have no conflict of interest.

\section{References}

1. Umesha, S.; Manukumar, H.M.G.; Chandrasekhar, B. Sustainable Agriculture and Food Security. In Biotechnology for Sustainable Agriculture; Singh, R.L., Mondal, S., Eds.; Elsevier Inc.: Gurgaon, India, 2018; pp. 67-92. ISBN 978-0-12-812160-3. [CrossRef]

2. Kumar, M.; Giri, V.P.; Pandey, S.; Gupta, A.; Patel, M.K.; Bajpai, A.B.; Jenkins, S.; Siddique, K.H.M. Plant-Growth-Promoting Rhizobacteria Emerging as an Effective Bioinoculant to Improve the Growth, Production, and Stress Tolerance of Vegetable Crops. Int. J. Mol. Sci. 2021, 22, 12245. [CrossRef] [PubMed]

3. Bhattacharyya, P.N.; Jha, D.K. Plant growth-promoting rhizobacteria (PGPR): Emergence in agriculture. World J. Microbiol. Biotechnol. 2012, 28, 1327-1350. [CrossRef] [PubMed]

4. Hashem, A.; Tabassum, B.; Fathi Abd Allah, E. Bacillus subtilis: A plant-growth promoting rhizobacterium that also impacts biotic stress. Saudi J. Biol. Sci. 2019, 26, 1291-1297. [CrossRef] [PubMed] 
5. Riaz, U.; Murtaza, D.G.; Anum, W.; Samreen, T.; Sarfraz, M. Plant Growth-Promoting Rhizobacteria (PGPR) as Biofertilizers and Biopesticides. In Microbiota and Biofertilizers, 1st ed.; Hakeem, K.R., Dar, G.H., Mehmood, M.A., Bhat, R.A., Eds.; Springer Nature: Cham, Switzerland, 2020; pp. 181-196. ISBN 978-3-030-48771-3. [CrossRef]

6. Mastouri, F.; Björkman, T.; Harman, G.E. Seed Treatment with Trichoderma harzianum Alleviates Biotic, Abiotic, and Physiological Stresses in Germinating Seeds and Seedlings. Phytopathology 2010, 100, 1213-1221. [CrossRef]

7. Khushdil, F.; Jan, F.G.; Jan, G.; Hamayun, M.; Iqbal, A.; Hussain, A.; Bibi, N. Salt stress alleviation in Pennisetum glaucum through secondary metabolites modulation by Aspergillus terreus L. Plant Physiol. Biochem. 2019, 144, 127-134. [CrossRef]

8. Khan, S.A.; Hamayun, M.; Yoon, H.; Kim, H.-Y.; Suh, S.-J.; Hwang, S.-K.; Kim, J.-M.; Lee, I.-J.; Choo, Y.-S.; Yoon, U.-H.; et al. Plant growth promotion and Penicillium citrinum. BMC Microbiol. 2008, 8, 231. [CrossRef] [PubMed]

9. FAOSTAT. Available online: http://www.fao.org/faostat/en/\#data/QC (accessed on 15 June 2020).

10. Frary, A.; Doganlar, S.; Daunay, M.C. Vegetables. In Genome Mapping and Molecular Breeding in Plants, 1st ed.; Kole, C., Ed.; Springer: Berlin, Germany, 2007; Volume 5, pp. 231-257.

11. Medakker, A.; Vijayaraghavan, V. Successful commercialization of insect-resistant eggplant by a public-private partnership: Reaching and benefiting resource-poor farmers. In Intellectual Property Management in Health and Agricultural Innovation A Handbook of Best Practices; Krattiger, A., Mahoney, R.T., Eds.; MIHR: Oxford, UK; PIPRA: Davis, CA, USA; Oswaldo Cruz Foundation: Rio de Janeiro, Brazil; Bio Developments-International Institute: Ithaca, NY, USA, 2010; pp. 1829-1831.

12. Singh, A. Soil salinity: A global threat to sustainable development. Soil Use Manag. 2021, 38, 39-67. [CrossRef]

13. Brevik, E.C.; Cerdà, A.; Mataix-Solera, J.; Pereg, L.; Quinton, J.N.; Six, J.; Van Oost, K. The interdisciplinary nature of SOIL. SOIL 2015, 1, 117-129. [CrossRef]

14. Ünlükara, A.; Kurunç, A.; Kesmez, G.D.; Yurtseven, E.; Suarez, D.L. Effects of salinity on eggplant (Solanum melongena L.) growth and evapotranspiration. Irrig. Drain. 2008, 59, 203-214.

15. Hannachi, S.; Van Labeke, M.-C. Salt stress affects germination, seedling growth and physiological responses differentially in eggplant cultivars (Solanum melongena L.). Sci. Hortic. 2018, 228, 56-65. [CrossRef]

16. Munns, R.; Tester, M. Mechanisms of salinity tolerance. Annu. Rev. Plant Biol. 2008, 59, 651-681. [CrossRef] [PubMed]

17. Safdarian, M.; Askari, H.; Shariati, J.V.; Nematzadeh, G. Transcriptional responses of wheat roots inoculated with Arthrobacter nitroguajacolicus to salt stress. Sci. Rep. 2019, 9, 1792. [CrossRef]

18. Ćurković-Perica, M.; Vršek, I.; Mitić, B. In vitro propagation of Inula verbascifolia (Willd.) Hausskn. subsp. verbascifolia. Plant Biosyst. 2008, 142, 1-4. [CrossRef]

19. Khayyat, M.; Rajaee, S.; Abdoreza, S.; Eshghi, S.; Tafazoli, E. Calcium effects on changes in chlorophyll contents, dry weight and micronutrients of strawberry (Fragaria $\times$ ananassa Duch.) plants under salt-stress conditions. Fruits 2009, 64, 53-59. [CrossRef]

20. Ha-Tran, D.M.; Nguyen, T.T.M.; Hung, S.-H.; Huang, E.; Huang, C.-C. Roles of Plant Growth-Promoting Rhizobacteria (PGPR) in Stimulating Salinity Stress Defense in Plants: A Review. Int. J. Mol. Sci. 2021, 22, 3154. [CrossRef] [PubMed]

21. Bharti, N.; Barnawal, D.; Awasthi, A.; Yadav, A.; Kalra, A. Plant growth promoting rhizobacteria alleviate salinity induced negative effects on growth, oil content and physiological status in Mentha arvensis. Acta Physiol. Plant 2014, 36, 45-60. [CrossRef]

22. Abd_Allah, E.F.; Alqarawi, A.A.; Hashem, A.; Radhakrishnan, R.; Al-Huqail, A.A.; Al-Otibi, F.O.N.; Malik, J.A.; Alharbi, R.I.; Egamberdieva, D. Endophytic bacterium Bacillus subtilis (BERA 71) improves salt tolerance in chickpea plants by regulating the plant defense mechanisms. J. Plant Interact. 2018, 13, 37-44. [CrossRef]

23. Khosravi, K.; Sartaj, M.; Tsai, F.T.-C.; Singh, V.P.; Kazakis, N.; Melesse, A.M.; Prakash, I.; Bui, D.T.; Pham, B.T. A comparison study of DRASTIC methods with various objective methods for groundwater vulnerability assessment. Sci. Total Environ. 2018, 642, 1032-1049. [CrossRef]

24. Taïbia, K.; Taïbia, F.; Abderrahima, L.A.; Ennajahb, A.; Belkhodjac, M.; Mulet, J.M. Effect of salt stress on growth, chlorophyll content, lipid peroxidation and antioxidant defense systems in Phaseolus vulgaris L. S. Afr. J. Bot. 2016, 105, 306-312. [CrossRef]

25. Taffouo, V.D.; Wamba, O.F.; Yombi, E.; Nono, G.V.; Akoa, A. Growth, yield, water status and ionic distribution response of three bambara groundnut (Vigna subterranean L. verdc.) landraces grown under saline conditions. Int. J. Bot. 2010, 6, 53-58. [CrossRef]

26. Ashraf, M. Relationships between leaf gas exchange characteristics and growth of differently adapted populations of Blue panicgrass (Panicum antidotale Retz.) under salinity or waterlogging. Plant Sci. 2003, 165, 69-75. [CrossRef]

27. Saleem, S.; Iqbal, A.; Ahmed, F.; Ahmad, M. Phytobeneficial and salt stress mitigating efficacy of IAA producing salt tolerant strains in Gossypium hirsutum. Saudi J. Biol. Sci. 2021, 28, 5317-5324. [CrossRef]

28. Abdelmoteleb, A.; Gonzalez-Mendoza, D. Isolation and Identification of Phosphate Solubilizing Bacillus spp. from Tamarix ramosissima Rhizosphere and Their Effect on Growth of Phaseolus vulgaris Under Salinity Stress. Geomicrobiol. J. 2020, 37, 901-908. [CrossRef]

29. Azarmi-Atajan, F.; Sayyari-Zohan, M.H. Alleviation of salt stress in lettuce (Lactuca sativa L.) by plant growth-promoting rhizobacteria. J. Hortic. Postharvest. Res. 2020, 3, 67-78.

30. Mishra, M.; Kumar, U.; Mishra, P.K.; Prakash, P. Efficiency of plant growth promoting rhizobacteria for the enhancement of Cicer arietinum L. growth and germination under salinity. Adv. Biol. Res. 2010, 4, 92-96.

31. Hannachi, S.; Werbrouck, S.; Bahrini, I.; Abdelgadir, A.; Siddiqui, H.A. Agronomical, Physiological and Biochemical Characterization of In Vitro Selected Eggplant Somaclonal Variants under NaCl Stress. Plants 2021, 10, 2544. [CrossRef]

32. Zribi, L.; Fatma, G.; Fatma, R.; Salwa, R.; Hassan, N.; Néjib, R.M. Application of chlorophyll fluorescence for the diagnosis of salt stress in tomato "Solanum lycopersicum (variety Rio Grande). Sci. Hortic. 2009, 120, 367-372. [CrossRef] 
33. Gallé, Ă.; Csiszăr, J.; Tari, I.; Erdei, L. Changes in water relation and chlorophyll fluorescence parameters under osmotic stress in wheat cultivars. Acta Biol. Szeged. 2002, 46, 85-86.

34. Yaghoubian, I.; Ghassemi, S.; Nazari, M.; Raei, Y.; Smith, D.L. Response of physiological traits, antioxidant enzymes and nutrient uptake of soybean to Azotobacter Chroococcum and zinc sulfate under salinity. S. Afr. J. Bot. 2021, 143, 42-51. [CrossRef]

35. Osman, H.; Gowayed, S.; Elbagory, M.; Omara, A.; El-Monem, A.; El-Razek, U.A.; Hafez, E. Interactive Impacts of Beneficial Microbes and Si-Zn Nanocomposite on Growth and Productivity of Soybean Subjected to Water Deficit under Salt-Affected Soil Conditions. Plants 2021, 10, 1396. [CrossRef] [PubMed]

36. Ashraf, M. Some important physiological selection criteria for salt tolerance in plants. Flora Morphol. Distrib. Funct. Ecol. Plants 2004, 199, 361-376. [CrossRef]

37. El-Dakak, R.; El-Aggan, W.; Badr, G.; Helaly, A.; Tammam, A. Positive Salt Tolerance Modulation via Vermicompost Regulation of SOS1 Gene Expression and Antioxidant Homeostasis in Viciafaba Plant. Plants 2021, 10, 2477. [CrossRef]

38. Halfter, U.; Ishitani, M.; Zhu, J.K. The Arabidopsis SOS2 protein kinase physically interacts with and is activated by the calcium-binding protein SOS3. Proc. Natl. Acad. Sci. USA 2000, 97, 3735-3740. [CrossRef]

39. Zhu, J.-K. Regulation of ion homeostasis under salt stress. Curr. Opin. Plant Biol. 2003, 6, 441-445. [CrossRef]

40. Hauer-Jákli, M.; Tränkner, M. Critical Leaf Magnesium Thresholds and the Impact of Magnesium on Plant Growth and PhotoOxidative Defense: A Systematic Review and Meta-Analysis From 70 Years of Research. Front. Plant Sci. 2019, 10, 766. [CrossRef] [PubMed]

41. Ceylan, B.; Khorshid, L.; Güneş, Ü.Y.; Zaybak, A. Evaluation of oxygen saturation values in different body positions in healthy individuals. J. Clin. Nurs. 2016, 25, 1095-1100. [CrossRef]

42. Desnoues, N.; Lin, M.; Guo, X.; Ma, L.; Carreño-Lopez, R.; Elmerich, C. Nitrogen fixation genetics and regulation in a Pseudomonas stutzeri strain associated with rice. Microbiology 2003, 149, 2251-2262. [CrossRef] [PubMed]

43. Abdel-Ghany, T.M.; AlAwlaqi, M.M. Molecular Identification of Rhizospheric Thermo-halotolerant Aspergillus terreus and its Correlation to Sustainable Agriculture. Bioresources 2018, 13, 8012-8023. [CrossRef]

44. Brenes, M.; Pérez, J.; González-Orenga, S.; Solana, A.; Boscaiu, M.; Prohens, J.; Plazas, M.; Fita, A.; Vicente, O. Comparative Studies on the Physiological and Biochemical Responses to Salt Stress of Eggplant (Solanum melongena) and Its Rootstock $S$. torvum. Agriculture 2020, 10, 328. [CrossRef]

45. Ilangumaran, G.; Smith, D.L. Plant Growth Promoting Rhizobacteria in Amelioration of Salinity Stress: A Systems Biology Perspective. Front. Plant Sci. 2017, 8, 1768. [CrossRef]

46. Zhou, C.; Ma, Z.; Zhu, L.; Xiao, X.; Xie, Y.; Zhu, J.; Wang, J. Rhizobacterial Strain Bacillus megaterium BOFC15 Induces Cellular Polyamine Changes that Improve Plant Growth and Drought Resistance. Int. J. Mol. Sci. 2016, 17, 976. [CrossRef]

47. Gill, S.S.; Tuteja, N. Reactive oxygen species and antioxidant machinery in abiotic stress tolerance in crop plants. Plant Physiol. Biochem. 2010, 48, 909-930. [CrossRef] [PubMed]

48. Zhang, G.-W.; Xu, S.-C.; Hu, Q.-Z.; Mao, W.-H.; Gong, Y.-M. Putrescine Plays a Positive Role in Salt-Tolerance Mechanisms by Reducing Oxidative Damage in Roots of Vegetable Soybean. J. Integr. Agric. 2014, 13, 349-357. [CrossRef]

49. Shi, K.; Huang, Y.Y.; Xia, X.J.; Zhang, Y.L.; Zhou, Y.H.; Yu, J.Q. Protective Role of Putrescine Against Salt Stress is Partially Related to the Improvement of Water Relation and Nutritional Imbalance in Cucumber. J. Plant Nutr. 2008, 31, 1820-1831. [CrossRef]

50. Zapata, P.J.; Serrano, M.; Pretel, M.; Amorós, A.; Botella, M. Ángeles Polyamines and ethylene changes during germination of different plant species under salinity. Plant Sci. 2004, 167, 781-788. [CrossRef]

51. El-Shintinawy, F. Photosynthesis in Two Wheat Cultivars Differing in Salt Susceptibility. Photosynthetica 2000, 38, 615-620. [CrossRef]

52. Xie, S.-S.; Wu, H.-J.; Zang, H.-Y.; Wu, L.-M.; Zhu, Q.-Q.; Gao, X.-W. Plant Growth Promotion by Spermidine-Producing Bacillus subtilis OKB105. MPMI 2014, 27, 655-663. [CrossRef] [PubMed]

53. Effects of salinity stress on growth and yield of two varieties of eggplant under greenhouse conditions. Res. Crop. 2018, 19, 436-440. [CrossRef]

54. Prittesh, P.; Avnika, P.; Kinjal, P.; Jinal, H.N.; Sakthivel, K.; Amaresan, N. Amelioration effect of salt-tolerant plant growthpromoting bacteria on growth and physiological properties of rice (Oryza sativa) under salt-stressed conditions. Arch. Microbiol. 2020, 202, 2419-2428. [CrossRef]

55. Komenda, J.; Reisinger, V.; Müller, B.C.; Dobáková, M.; Granvogl, B.; Eichacker, L.A. Accumulation of the D2 Protein Is a Key Regulatory Step for Assembly of the Photosystem II Reaction Center Complex in Synechocystis PCC 6803. J. Biol. Chem. 2004, 279, 48620-48629. [CrossRef]

56. Minai, L.; Wostrikoff, K.; Wollman, F.-A.; Choquet, Y. Chloroplast Biogenesis of Photosystem II Cores Involves a Series of Assembly-Controlled Steps That Regulate Translation. Plant Cell 2006, 18, 159-175. [CrossRef] [PubMed]

57. Chen, J.; Zhang, H.; Zhang, X.; Tang, M. Arbuscular Mycorrhizal Symbiosis Alleviates Salt Stress in Black Locust through Improved Photosynthesis, Water Status, and $\mathrm{K}+/ \mathrm{Na}+$ Homeostasis. Front. Plant Sci. 2017, 8, 1739. [CrossRef]

58. Trivedi, D.K.; Gill, S.S.; Yadav, S.; Tuteja, N. Genome-wide analysis of glutathione reductase (GR) genes from rice and Arabidopsis Plant Signal. Behav. 2013, 8, e23021. [CrossRef] [PubMed]

59. Gururani, M.A.; Venkatesh, J.; Upadhyaya, C.P.; Nookaraju, A.; Pandey, S.K.; Park, S.W. Plant disease resistance genes: Current status and future directions. Physiol. Mol. Plant Pathol. 2012, 78, 51-65. [CrossRef] 
60. Habib, S.H.; Kausar, H.; Saud, H.M. Plant Growth-Promoting Rhizobacteria Enhance Salinity Stress Tolerance in Okra through ROS-Scavenging Enzymes. BioMed Res. Int. 2016, 2016, 6284547. [CrossRef] [PubMed]

61. Chen, I.; Chiu, M.; Cheng, S.; Hsu, Y.; Tsai, C. The glutathione transferase of Nicotiana benthamiana Nb GSTU 4 plays a role in regulating the early replication of Bamboo mosaic virus. New Phytol. 2013, 199, 749-757. [CrossRef]

62. Jia, B.; Sun, M.; Sun, X.; Li, R.; Wang, Z.; Wu, J.; Wei, Z.; Duanmu, H.; Xiao, J.; Zhu, Y. Overexpression of GsGSTU13 and SCMRP in Medicago sativa confers increased salt-alkaline tolerance and methionine content. Physiol. Plant 2015, 156, 176-189. [CrossRef] [PubMed]

63. Xu, J.; Xing, X.-J.; Tian, Y.-S.; Peng, R.-H.; Xue, Y.; Zhao, W.; Yao, Q.-H. Transgenic Arabidopsis Plants Expressing Tomato Glutathione S-Transferase Showed Enhanced Resistance to Salt and Drought Stress. PLoS ONE 2015, 10, e0136960. [CrossRef]

64. Mostofa, M.G.; Hossain, M.A.; Fujita, M. Trehalose pretreatment induces salt tolerance in rice (Oryza sativa L.) seedlings: Oxidative damage and co-induction of antioxidant defense and glyoxalase systems. Protoplasma 2015, 252, 461-475. [CrossRef]

65. Sappl, P.G.; Carroll, A.J.; Clifton, R.; Lister, R.; Whelan, J.; Millar, A.H.; Singh, K.B. The Arabidopsis glutathione transferase gene family displays complex stress regulation and co-silencing multiple genes results in altered metabolic sensitivity to oxidative stress. Plant J. 2009, 58, 53-68. [CrossRef]

66. Kissoudis, C.; Kalloniati, C.; Flemetakis, E.; Madesis, P.; Labrou, N.; Tsaftaris, A.; Nianiou-Obeidat, I. Stress-inducible GmGSTU4 shapes transgenic tobacco plants metabolome towards increased salinity tolerance. Acta Physiol. Plant 2015, 37, e102. [CrossRef]

67. Wang, K.; Durrett, T.P.; Benning, C. Functional diversity of glycerolipid acylhydrolases in plant metabolism and physiology. Prog. Lipid Res. 2019, 75, 100987. [CrossRef]

68. Lu, J.; Xu, Y.; Wang, J.; Singer, S.D.; Chen, G. The Role of Triacylglycerol in Plant Stress Response. Plants 2020, 9, 472. [CrossRef]

69. Singh, R.P.; Jha, P.N. The Multifarious PGPR Serratia marcescens CDP-13 Augments Induced Systemic Resistance and Enhanced Salinity Tolerance of Wheat (Triticum aestivum L.). PLoS ONE 2016, 11, e0155026. [CrossRef]

70. Cook, R.; Lupette, J.; Benning, C. The Role of Chloroplast Membrane Lipid Metabolism in Plant Environmental Responses. Cells 2021, 10, 706. [CrossRef]

71. Beneduzi, A.; Ambrosini, A.; Passaglia, L.M. Plant growth-promoting rhizobacteria (PGPR): Their potential as antagonists and biocontrol agents. Genet. Mol. Biol. 2012, 35, 1044-1051. [CrossRef] [PubMed]

72. Aminisarte, M. Biological Control of Meloidogyne incognita on Eggplant (Solanum melongena). Asian J. Plant Sci. 2021, 21, 1-8. [CrossRef]

73. Siddiqui, I.A.; Ehetshamul-Haque, S.; Shaukat, S.S. Use of Rhizobacteria in the Control of Root Rot-Root Knot Disease Complex of Mungbean. J. Phytopathol. 2001, 149, 337-346. [CrossRef]

74. Schönbeck, F.; Dehne, H.W.; Beicht, W. Untersuchungen zur Aktivierung unspezifischer Resistenzmechanismen in Pflanzen. Z. Pflk. Pflschutz 1980, 87, 654-666.

75. Behera, B.C.; Sethi, B.K.; Mohapatra, S.; Thatoi, H.; Mishra, R.R. Bio-production of alkaline protease by Trichoderma longibrachiatum and Penicillium rubidurum using different agro-industrial products. Nov. Res. Microbiol. J. 2021, 5, 1241-1255. [CrossRef]

76. Abu-Tahon, M.A.; Arafat, H.H.; Isaac, G.S. Laundry Detergent Compatibility and Dehairing Efficiency of Alkaline Thermostable Protease Produced from Aspergillus terreus under Solid-state Fermentation. J. Oleo Sci. 2020, 69, 241-254. [CrossRef]

77. Alkhafaje, W.K.; Ali, S.M.; Olama, Z.A. Isolation and molecular differentiation of MDR bacteria isolated from dairy products. Pollut. Res. 2019, 38, 109-115.

78. Hassan, S.W.M.; El-Latif, H.H.A.; Ali, S.M. Production of Cold-Active Lipase by Free and Immobilized Marine Bacillus cereus HSS: Application in Wastewater Treatment. Front. Microbiol. 2018, 9, 2377. [CrossRef]

79. Pitt, J.I.; Hocking, A.D. Fungi and Food Spoilage, 3rd ed.; Springer: Boston, MA, USA, 2009; p. 519. [CrossRef]

80. Domsch, K.H.; Gams, W.; Anderson, T.H. Compendium of Soil Fungi, 2nd ed.; IHW-Verlg Eching: Eching, Germany, $2007 ;$ p. 672.

81. Harman, G.E.; Kubicek, C.P. Trichoderma And Gliocladium. Volume 1: Basic Biology, Taxonomy and Genetics, 1st ed.; CRC Press: London, UK, 1998; p. 300.

82. Houbraken, J.; Frisvad, J.; Samson, R. Taxonomy of Penicillium section Citrina. Stud. Mycol. 2011, 70, 53-138. [CrossRef] [PubMed]

83. Ikeuchi, T.; Ishida, A.; Tajifi, M.; Nagata, S. Induction of salt tolerance in Bacillus subtilis IFO 3025. J. Biosci. Bioeng. 2003, 96, 184-186. [CrossRef]

84. Latif, S.; Mohamed, A.; Sueyoshi, K.; Mohamed, H.; Saber, N. Effect of Bacillus subtilis on Some Physiological and Biochemical Processes in Barley (Hordeum vulgare L.) Plant Grown under Salt Stress. Egypt. J. Bot. 2020, 61, 141-153. [CrossRef]

85. Fall, R.; Kinsinger, R.F.; Wheeler, K.A. A Simple Method to Isolate Biofilm-forming Bacillus subtilis and Related Species from Plant Roots. Syst. Appl. Microbiol. 2004, 27, 372-379. [CrossRef] [PubMed]

86. Lastochkina, O.; Baymiev, A.; Shayahmetova, A.; Garshina, D.; Koryakov, I.; Shpirnaya, I.; Pusenkova, L.; Mardanshin, I.; Kasnak, C.; Palamutoglu, R. Effects of Endophytic Bacillus Subtilis and Salicylic Acid on Postharvest Diseases (Phytophthora infestans, Fusarium oxysporum) Development in Stored Potato Tubers. Plants 2020, 9, 76. [CrossRef]

87. Preston, G.M. Plant perceptions of plant growth-promoting Pseudomonas. Philos. Trans. R. Soc. B Biol. Sci. 2004, 359, 907-918. [CrossRef] 
88. Egamberdieva, D.; Li, L.; Lindstrom, K.; Räsänen, L.A. A synergistic interaction between salt-tolerant Pseudomonas and Mesorhizobium strains improves growth and symbiotic performance of liquorice (Glycyrrhiza uralensis Fish.) under salt stress. Appl. Microbiol. Biotechnol. 2016, 100, 2829-2841. [CrossRef]

89. Vimal, S.R.; Gupta, J.; Singh, J.S. Effect of salt tolerant Bacillus sp. and Pseudomonas sp. on wheat (Triticum aestivum L.) growth under soil salinity: A comparative study. Microbiol. Res. 2018, 9, 26-32. [CrossRef]

90. Gupta, S.; Smith, P.M.C.; Boughton, B.A.; Rupasinghe, T.W.T.; Natera, S.H.A.; Roessner, U. Inoculation of barley with Trichoderma harzianum T-22 modifies lipids and metabolites to improve salt tolerance. J. Exp. Bot. 2021, 72, 7229-7246. [CrossRef] [PubMed]

91. Zin, N.A.; Badaluddin, N.A. Biological functions of Trichoderma spp. for agriculture applications. Ann. Agric. Sci. 2020, 65, 168-178. [CrossRef]

92. Bae, H.; Roberts, D.P.; Lim, H.-S.; Strem, M.D.; Park, S.-C.; Ryu, C.-M.; Melnick, R.L.; Bailey, B.A. Endophytic Trichoderma Isolates from Tropical Environments Delay Disease Onset and Induce Resistance Against Phytophthora capsici in Hot Pepper Using Multiple Mechanisms. MPMI 2011, 24, 336-351. [CrossRef] [PubMed]

93. Hung, R.; Lee Rutgers, S. Applications of Aspergillus in Plant Growth Promotion. In New and Future Developments in Microbial Biotechnology and Bioengineering; Gupta, V.K., Ed.; Elsevier: Amsterdam, The Netherlands, 2016; pp. 223-227. ISBN 9780444635051. [CrossRef]

94. Vassileva, M.; Malusá, E.; Eichler-Löbermann, B.; Vassilev, N. Aspegillus terreus: From Soil to Industry and Back. Microorganisms 2020, 8, 1655. [CrossRef] [PubMed]

95. Pang, K.-L.; Chiang, M.W.-L.; Guo, S.-Y.; Shih, C.-Y.; Dahms, H.U.; Hwang, J.-S.; Cha, H.-J. Growth study under combined effects of temperature, $\mathrm{pH}$ and salinity and transcriptome analysis revealed adaptations of Aspergillus terreus NTOU4989 to the extreme conditions at Kueishan Island Hydrothermal Vent Field, Taiwan. PLoS ONE 2020, 15, e0233621. [CrossRef]

96. Dhakar, K.; Sharma, A.; Pandey, A. Cold, pH and salt tolerant Penicillium spp. inhabit the high altitude soils in Himalaya, India. World J. Microbiol. Biotechnol. 2014, 30, 1315-1324. [CrossRef]

97. Saleem, M.; Arshad, M.; Hussain, S.; Bhatti, A.S. Perspective of plant growth promoting rhizobacteria (PGPR) containing ACC deaminase in stress agriculture. J. Ind. Microbiol. Biotechnol. 2007, 34, 635-648. [CrossRef]

98. Wu, H.; Guo, J.; Wang, C.; Li, K.; Zhang, X.; Yangm, Z.; Li, M.; Wang, B. An Effective Screening method and an eliable screening trait for salt tolerance of Brassica napus at the germination stage. Front. Plant Sci. 2019, 10, 530. [CrossRef]

99. Lichtenthaler, H.K. Chlorophylls and carotenoids: Pigments of photosynthetic biomembranes. Methods Enzymol. 1987, 148, 350-382.

100. Moustakas, M.; Ouzounidou, G.; Lannoye, R. Rapid Screening for Aluminum Tolerance in Cereals by Use of the Chlorophyll Fluorescence Test. Plant Breed. 1993, 111, 343-346. [CrossRef]

101. Kimbrough, D.E.; Wakakuwa, J.R. Acid digestion for sediments, sludges, soils, and solid wastes. A proposed alternative to EPA SW 846 Method 3050. Environ. Sci. Technol. 1989, 23, 898-900. [CrossRef]

102. Gong, X.; Liu, J.H. Detection of Free Polyamines in Plants Subjected to Abiotic Stresses by High-Performance Liquid Chromatography (HPLC). In Plant Stress Tolerance. Methods in Molecular Biology; Sunkar, R., Ed.; Humana Press: New York, NY, USA, 2017; Volume 1631, pp. 305-311. [CrossRef]

103. IBM Corp. IBM SPSS Statistics for Windows, Version 21.0; IBM Corp.: Armonk, NY, USA, 2012.

104. Zhang, P.; Ma, Y.; Xie, C.; Guo, Z.; He, X.; Valsami-Jones, E.; Lynch, I.; Luo, W.; Zheng, L.; Zhang, Z. Plant species-dependent transformation and translocation of ceria nanoparticles. Environ. Sci. Nano 2019, 6, 60-67. [CrossRef]

105. Sokal, R.R.; Rohlf, F. Biometry: The Principles and Practice of Statistics in Biological Research; Correa, J., Ed.; W. H. Freeman and Company: New York, NY, USA, 2012; pp. 177-602. 